\title{
Phytochemical Profiling, In Vitro Biological Activities, and In Silico Molecular Docking Studies of Dracaena reflexa
}

\author{
Bilal Ahmad Ghalloo ${ }^{1}$, Kashif-ur-Rehman Khan ${ }^{1, *}$, Saeed Ahmad ${ }^{1}$, Hanan Y. Aati ${ }^{2, *(D)}$, Jawaher H. Al-Qahtani ${ }^{2}$,
} Barkat Ali ${ }^{3}$, Imran Mukhtar ${ }^{4}$, Musaddique Hussain ${ }^{5}$, Muhammad Nadeem Shahzad ${ }^{1}$ and Imtiaz Ahmed ${ }^{1}$

1 Department of Pharmaceutical Chemistry, Faculty of Pharmacy, The Islamia University of Bahawalpur, Bahawalpur 63100, Pakistan; drbilal29@hotmail.com (B.A.G.); rsahmed_iub@yahoo.com (S.A.); shazad_sca@yahoo.com (M.N.S.); imtiaz.pharmacist2011@gmail.com (I.A.)

2 Department of Pharmacognosy, College of Pharmacy, King Saud University, Riyadh 11495, Saudi Arabia jalqahtani@ksu.edu.sa

3 National Agri Research Institute-NARC, Park Road Chack Shahzad Islamabad, Islamabad 45600, Pakistan bkfoodschem@yahoo.com

4 Faculty of Medicine \& Allied Health Sciences, Sir Sadiq Muhammad Khan Abbasi Post Graduate Medical College, The Islamia University of Bahawalpur, Bahawalpur 63100, Pakistan; imran.mukhtar@iub.edu.pk

5 Department of Pharmacology, Faculty of Pharmacy, The Islamia University of Bahawalpur, Bahawalpur 63100, Pakistan; musaddique.hussain@iub.edu.pk

* Correspondence: kashifur.rehman@iub.edu.pk (K.-u.-R.K.); hati@ksu.edu.sa (H.Y.A.); Tel.: 92-3366708638 (K.-u.-R.K.)

check for updates

Citation: Ghalloo, B.A.; Khan, K.-u.-R.; Ahmad, S.; Aati, H.Y.; Al-Qahtani, J.H.; Ali, B.; Mukhtar, I.; Hussain, M.; Shahzad, M.N.; Ahmed, I. Phytochemical Profiling, In Vitro Biological Activities, and In Silico Molecular Docking Studies of Dracaena reflexa. Molecules 2022, 27, 913. https://doi.org/10.3390/ molecules 27030913

Academic Editors: Mohamed L. Ashour, Nawal M. Al Musayeib and Fadia S. Youssef

Received: 16 December 2021

Accepted: 25 January 2022

Published: 28 January 2022

Publisher's Note: MDPI stays neutral with regard to jurisdictional claims in published maps and institutional affiliations.

Copyright: (C) 2022 by the authors. Licensee MDPI, Basel, Switzerland. This article is an open access article distributed under the terms and conditions of the Creative Commons Attribution (CC BY) license (https:// creativecommons.org/licenses/by/ $4.0 /)$.

\begin{abstract}
Dracaena reflexa, a traditionally significant medicinal plant, has not been extensively explored before for its phytochemical and biological potential. The present study was conducted to evaluate the bioactive phytochemicals and in vitro biological activities of D. reflexa, and perform in silico molecular docking validation of D. reflexa. The bioactive phytochemicals were assessed by preliminary phytochemical testing, total bioactive contents, and GC-MS analysis. For biological evaluation, the antioxidant (DPPH, ABTS, CUPRAC, and ABTS), antibacterial, thrombolytic, and enzyme inhibition (tyrosinase and cholinesterase enzymes) potential were determined. The highest level of total phenolic contents $(92.72 \pm 0.79 \mathrm{mg} \mathrm{GAE} / \mathrm{g}$ extract) was found in the $n$-butanol fraction while the maximum total flavonoid content $(110 \pm 0.83 \mathrm{mg} Q \mathrm{QE} / \mathrm{g}$ extract) was observed in methanolic extract. The results showed that $n$-butanol fraction exhibited very significant tyrosinase inhibition activity $(73.46 \pm 0.80)$ and acetylcholinesterase inhibition activity $(64.06 \pm 2.65 \%)$ as compared to other fractions and comparable to the standard compounds (kojic acid and galantamine). The methanolic extract was considered to have moderate butyrylcholinesterase inhibition activity $(50.97 \pm 063)$ as compared to the standard compound galantamine (53.671 $\pm 0.97 \%)$. The GC-MS analysis of the $n$-hexane fraction resulted in the tentative identification of 120 bioactive phytochemicals. Furthermore, the major compounds as identified by GC-MS were analyzed using in silico molecular docking studies to determine the binding affinity between the ligands and the enzymes (tyrosinase, acetylcholinesterase, and butyrylcholinesterase enzymes). The results of this study suggest that Dracaena reflexa has unquestionable pharmaceutical importance and it should be further explored for the isolation of secondary metabolites that can be employed for the treatment of different diseases.
\end{abstract}

Keywords: Dracaena reflexa; methanolic extract; antioxidant; antibacterial; enzyme inhibition activity; GC-MS; molecular docking

\section{Introduction}

Medicinal plants represent a rich source of novel lead compounds that contribute to various therapeutic and pharmacological activities [1]. Around 25\% of the pharmaceutical products used in the modern era were developed from plants [2]. According to WHO, nearly $80 \%$ of the world population consume the products of medicinal plants to cure 
different diseases [3]. In many studies, it is reported that antioxidant, anti-inflammatory, anticancer, antiviral, antibacterial, antifungal, insecticidal, antimalarial, anti-aging, and various other therapeutic activities depend on a significant variety of secondary metabolites (glucosinolates, lycopenes, anthocyanidins, flavonoids, isoflavonoids, polyphenols, limonoids, carotenoids, phytoestrogens, and omega-3 fatty acids, etc.) that are isolated from potential medicinal plants with the help of advanced, sensitive, and sophisticated equipment. Under these characteristics, about 20,000 plant species have been explored for their medicinal purposes [4].

Reactive oxygen species (ROS) are formed by cellular metabolism or some exogenous factors, such as drugs, chemicals, smoke, and environmental stress conditions. The ROS structure contains at least one unpaired electron [5]. The risk is related to the accumulation of these agents in the body, resulting in a radical reactions chain, which degrades many biological vital molecules, namely DNA, proteins, lipids, and carbohydrates [6]. It has been revealed that ROS are associated with some diseases, such as diabetes mellitus, insulin resistance, cardiovascular diseases, Alzheimer's disease, Parkinson's disease, and some types of cancer [7]. Indeed, antioxidants of natural origin have received significant interest regarding exploration to identify secondary metabolites for the health and food industry. Antioxidants can maintain health by scavenging radicals and reactive oxygen species [8]. It is reported that two-thirds of all plant species have medicinal value and antioxidant potential [9].

Browning and hyperpigmentation in human skin are two common undesirable phenomena and tyrosinase is the major enzyme responsible for this browning and hyperpigmentation in mammals [10]. Due to the demand for tyrosinase inhibitors, researchers and scientists are actively engaged in the identification, isolation, and synthesis of new moieties for various applications in the food, cosmetics, and medicinal industries [11]. In addition, more improvements of in vitro detection methods for rapid analysis of tyrosinase inhibitors may be achieved through the use of virtual analysis [12]. Thus, a combination of bioinformatics simulation and biological in vitro screening will be advantageous to understand the functional mechanisms of the tested extracts [13].

Acetylcholinesterase and butyrylcholinesterase enzymes are known for hydrolyzing acetylcholine in the synaptic cleft of the brain [14]. Alzheimer's disease (AD) is a neurological disorder, mediated by an acetylcholine deficiency, expressed by increased degeneration of brain tissue, which generally affects the memory and behavior of elderly people worldwide [15]. Hence, by maintaining the acetylcholine levels for neurotransmission in the synaptic cleft, the symptoms of AD can be reduced or prevented. Therefore, scientists have been fascinated by cholinesterase inhibitive treatment for asymptomatic management. Significant evidence has accumulated over the years showing that an interaction probably exists between $\mathrm{AD}$ and epilepsy. Individuals suffering from epilepsy often experience cognitive impairment and acetylcholinesterase disorders [16]. It has been proven that secondary metabolites from plants display cholinesterase inhibition, which can potentially be utilized for the management of AD and epilepsy [17].

Dracaena is considered among the most representative genera of the Asparagaceae, endemic in Africa, southern Asia, northern Australia, and tropical Central America, with approximately 120 species. Different species of Dracaena are used as ornamentals and medicinal plants, and are also used in research and as colorants, etc. Owing to its richly colored evergreen leaves and thick irregular stems, in Europe and Canada, Dracaena species are grown and sold as ornamentals [18]. It was reported that Dracaena is a source of different groups of secondary metabolites, largely terpenoids, tannins, glycosides, lignans, phenols, and flavonoids. These secondary metabolites reflect its biological activities, in vitro lipid peroxidation, antioxidant potential, anti-inflammatory activity, antimicrobial activity, and cytotoxicity [19]. D. reflexa is one of the plants used in the NASA Clean Air Study and has been shown to help in the detoxification of formaldehyde [20]. Traditional healers from Madagascar believe that D. reflexa can cure symptoms of malaria, poisoning, dysentery, diarrhea, and dysmenorrhea, and be efficacious as an antipyretic and hemostatic agent. 
The leaves and bark of $D$. reflexa are mixed with the parts of many other native plants to prepare herbal teas [21]. The objective of this study was to evaluate the phytochemical and in vitro biological activities of $D$. reflexa and to perform in silico molecular docking analysis of methanolic extract and $n$-hexane, chloroform, and $n$-butanol fractions in the D. reflexa plant.

\section{Results}

\subsection{Phytochemical Analysis}

\subsubsection{Preliminary Phytochemical Analysis}

Preliminary phytochemical analysis of methanolic extract (DRME), $n$-hexane fraction (DRHF), chloroform fraction (DRCF), and $n$-butanol fraction (DRBF) of Dracaena reflexa was performed. This analysis revealed the presence of various primary and secondary metabolites. A minor carbohydrate concentration was observed while amino acids and proteins were not identified in any of the extract/fractions. Lipids were found to be abundant in DRBF and the lowest in DRHF. Amongst the secondary metabolites, alkaloids were found to be present in DRHF and DRCF, tannins and phenols were observed in all extracts / fractions, flavonoids and saponins were found to be abundant in DRME and DRBF, steroids and glycosides were identified in a minute quantity in these extracts/fractions, and resins were not detected in any of the extracts/fractions (Table 1).

Table 1. Phytochemical analysis of extracts/fractions of Dracaena reflexa.

\begin{tabular}{|c|c|c|c|c|c|c|}
\hline & Metabolites & Tests & DRME & DRHF & DRCF & DRBF \\
\hline \multicolumn{7}{|c|}{ Primary Metabolites } \\
\hline \multirow{2}{*}{1.} & \multirow{2}{*}{ Carbohydrates } & Molisch's Test & + & - & + & + \\
\hline & & Fehling's Test & + & - & - & - \\
\hline 2. & Amino acids & Ninhydrin Test & - & - & - & - \\
\hline 3. & Proteins & Burette Test & - & - & - & - \\
\hline \multirow[t]{2}{*}{4.} & Lipids & Saponification Test & + & + & + & + \\
\hline & \multicolumn{6}{|c|}{ Secondary Metabolites } \\
\hline \multirow{3}{*}{1.} & \multirow{3}{*}{ Alkaloids } & Hager's Test & - & + & + & - \\
\hline & & Wagner's Test & - & + & - & - \\
\hline & & Mayer's Test & - & + & - & - \\
\hline 2. & Tannins & Lead Acetate Test & + & + & + & + \\
\hline 3. & Phenols & Ferric chloride test & + & + & + & + \\
\hline 4. & Flavonoids & Reaction with $\mathrm{NaOH}$ & + & - & + & + \\
\hline 5. & Saponins & Froth Test & + & - & - & + \\
\hline 6. & Steroids & Salkowaski's Test & + & + & + & + \\
\hline 7. & Glycosides & Erdmann's Test & + & - & - & + \\
\hline 8. & Resins & Acetic Anhydride Test & - & - & - & - \\
\hline
\end{tabular}

DRME: methanolic extract; DRHF: $n$-hexane fraction; DRCF: chloroform fraction; and DRBF: $n$-butanol fraction. + present; and -: absent.

\subsubsection{Total Phenolic and Flavonoids Contents (TPC and TFC)}

The highest level of TPC was found in DRBF, with a value of $92.72 \pm 0.79 \mathrm{mg}$ of gallic acid equivalents per gram of dry extract (mg GAE/g extract), while $44.72 \pm 0.79 \mathrm{mg} \mathrm{GAE} / \mathrm{g}$ extract was identified as the lowest level in DRHF.

The maximum value of TFC was observed in DRME (110 $\pm 0.83 \mathrm{mg}$ of quercetin equivalents per gram of dry extract, $\mathrm{mg} \mathrm{QE} / \mathrm{g}$ extract) and the minimum value was observed in DRHF (25.29 $\pm 4.16 \mathrm{mg}$ QE/g extract). The TFC values of DRBF and DRME 
$(105.88 \pm 1.66$ and $110 \pm 0.83 \mathrm{mg} \mathrm{QE} / \mathrm{g}$ extract, respectively) were observed to $\mathrm{b}$ nearly equal. These values predict the potential biological activities (Figure 1 and Table 2).

(A)

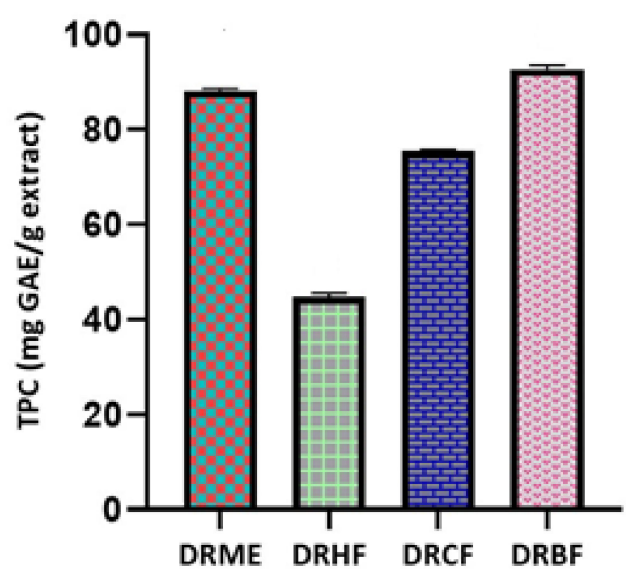

(B)

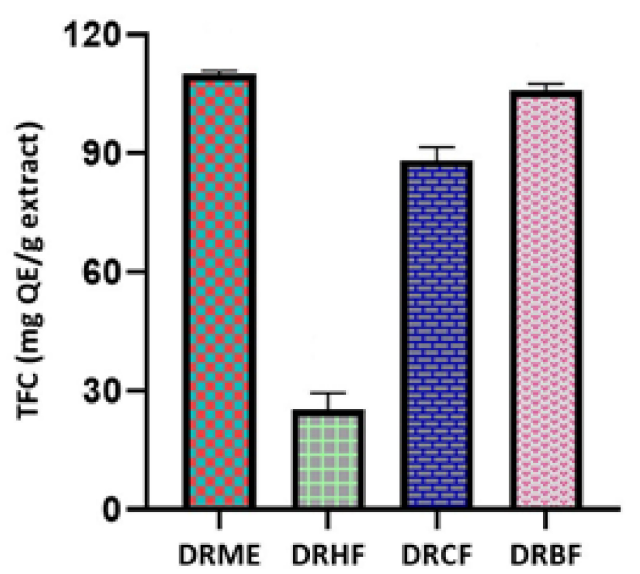

Figure 1. (A) Total phenolic contents (TPC) and (B) total flavonoid contents (TFC) of Dracaena reflexa extract/fractions. DRME: methanolic extract; DRHF: $n$-hexane fraction; DRCF: chloroform fraction; and DRBF: $n$-butanol fraction.

Table 2. TPC, TFC, DPPH, ABTS, CUPRAC, and FRAP values for extract/fractions of Dracaena reflexa.

\begin{tabular}{ccccccc}
\hline $\begin{array}{c}\text { Extract/ } \\
\text { Fractions } \\
\text { Name }\end{array}$ & $\begin{array}{c}\text { TPC } \\
\text { (mg GAE/g } \\
\text { Extract) }\end{array}$ & $\begin{array}{c}\text { TFC } \\
\text { (mg QE/g } \\
\text { Extract) }\end{array}$ & $\begin{array}{c}\text { DPPH } \\
\text { (mg TE/g } \\
\text { Extract) }\end{array}$ & $\begin{array}{c}\text { ABTS } \\
\text { (mg TE/g } \\
\text { Extract) }\end{array}$ & $\begin{array}{c}\text { CUPRAC } \\
\text { (mg TE/g } \\
\text { Extract) }\end{array}$ & $\begin{array}{c}\text { FRAP } \\
\text { (mg TE/g } \\
\text { Extract) }\end{array}$ \\
\hline DRME & $88.16 \pm 0.45$ & $110 \pm 0.83$ & $82.06 \pm 2.38$ & $50.05 \pm 1.42$ & $243.25 \pm 2.05$ & $97.47 \pm 0.93$ \\
DRHF & $44.72 \pm 0.79$ & $25.29 \pm 4.16$ & $55.61 \pm 0.94$ & $39.22 \pm 0.56$ & $201.80 \pm 0.82$ & $86.04 \pm 1.24$ \\
DRCF & $75.44 \pm 0.33$ & $88.24 \pm 3.33$ & $91.21 \pm 1.02$ & $65.34 \pm 0.80$ & $266.87 \pm 2.66$ & $104.34 \pm 0.7$ \\
DRBF & $92.72 \pm 0.79$ & $105.88 \pm 1.66$ & $102.66 \pm 2.55$ & $82.50 \pm 0.37$ & $295.85 \pm 1.43$ & $112.42 \pm 1.86$
\end{tabular}

DRME: methanolic extract; DRHF: $n$-hexane fraction; DRCF: chloroform fraction; and DRBF $n$-butanol fraction.

\subsubsection{Tentative Identification of Metabolites by GC-MS Analysis}

Non-polar compounds are present in the $n$-hexane fraction of Dracaena reflexa. The use of GC-MS analysis is preferable for non-polar compounds. The $n$-hexane fraction of Dracaena reflexa (DRHF) was subjected to gas chromatography-mass spectrometry (GC-MS). The NIST library was used for the identification of metabolites and 121 compounds were tentatively identified. Finally, compounds with a similarity index of more than $90 \%$ were selected and are shown in the table.

The retention time in minutes (RT), area percentage (area \%), compound name, molecular formula (M.F.), chemical class (Class), molecular weight (M.W.), pharmacological activity (Pharm. Activity), and reference pharmacological activity of the metabolites detected in the DRHF by GC-MS are shown in Table 3. The major compounds identified were $n$-hexadecanoic acid, 9,12-octadecadienoic acid, methyl ester, 9,12,15-octadecatrienoic acid, methyl ester, octadecanoic acid, 1,2-benzenedicarboxylic acid, monophenyl ester, sodium salt, gamma-tocopherol, vitamin E, and beta-sitosterol (Figure 2 and Table 3). 
Table 3. Metabolic profile of the $n$-hexane fraction in Dracaena reflexa by GC-MS analysis.

\begin{tabular}{|c|c|c|c|c|c|c|c|}
\hline $\begin{array}{l}\text { Sr. } \\
\text { No. }\end{array}$ & R.T. & $\begin{array}{c}\% \\
\text { Area }\end{array}$ & Compound Name & M.F. & M.W. & Pharm. Activity & Class \\
\hline 1 & 3.13 & 0.5 & $p$-Xylene & $\mathrm{C}_{8} \mathrm{H}_{10}$ & 106.16 & CNS depression [22] & $\begin{array}{c}\text { Benzene } \\
\text { Derivatives }\end{array}$ \\
\hline 2 & 6.63 & 0.14 & Dodecane & $\mathrm{C}_{12} \mathrm{H}_{26}$ & 170.33 & $\begin{array}{c}\text { Antifungal } \\
\text { antioxidant } \\
\text { antibacterial [23] }\end{array}$ & Alkanes \\
\hline 3 & 7.16 & 0.07 & Dimethyl adipate & $\mathrm{C}_{10} \mathrm{H}_{14} \mathrm{O}_{4}$ & 198.22 & $\begin{array}{l}\text { Initiate growth inhibition, } \\
\text { induce apoptosis in cancer } \\
\text { cells [24] }\end{array}$ & Esters \\
\hline 4 & 7.82 & 0.07 & Tridecane & $\mathrm{C}_{13} \mathrm{H}_{28}$ & 184.36 & Antimicrobial [25] & Alkanes \\
\hline 5 & 8.93 & 0.07 & 1-Tetradecene & $\mathrm{C}_{14} \mathrm{H}_{28}$ & 196.22 & Anti-TB [26] & Alkenes \\
\hline 6 & 9.03 & 0.2 & Tetradecane & $\mathrm{C}_{14} \mathrm{H}_{30}$ & 198.39 & $\begin{array}{l}\text { Antibacterial } \\
\text { antifungal [26] }\end{array}$ & Alkanes \\
\hline 7 & 9.72 & 0.07 & $\begin{array}{c}\text { 5,9-Undecadien-2- } \\
\text { one, 6,10-dimethyl-, } \\
\text { (E)- }\end{array}$ & $\mathrm{C}_{13} \mathrm{H}_{22} \mathrm{O}$ & 194.31 & Antibacterial [27] & $\begin{array}{l}\text { Aliphatic } \\
\text { ketones }\end{array}$ \\
\hline 8 & 10.22 & 0.25 & Pentadecane & $\mathrm{C}_{15} \mathrm{H}_{32}$ & 212.42 & Antibacterial [27] & Alkanes \\
\hline 9 & 10.33 & 0.43 & $\begin{array}{c}1,4- \\
\text { Benzenedicarboxylic } \\
\text { acid, monobutyl } \\
\text { ester }\end{array}$ & $\mathrm{C}_{12} \mathrm{H}_{14} \mathrm{O}_{2}$ & 222.24 & Antimicrobial [28] & $\begin{array}{c}\text { Carbonylbenzoic } \\
\text { Acids }\end{array}$ \\
\hline 10 & 10.41 & 0.57 & $\begin{array}{l}\text { Phenol, 2,4-bis(1,1- } \\
\text { dimethylethyl)-6-(1- } \\
\text { phenylethyl)- }\end{array}$ & $\mathrm{C}_{22} \mathrm{H}_{30} \mathrm{O}$ & 310.5 & Antifungal [29] & $\begin{array}{l}\text { Aromatic } \\
\text { Phenols }\end{array}$ \\
\hline 11 & 10.82 & 0.24 & $\begin{array}{c}2(4 \mathrm{H})- \\
\text { Benzofuranone, } \\
5,6,7,7 \text { a-tetrahydro- }\end{array}$ & $\mathrm{C}_{8} \mathrm{H}_{10} \mathrm{O}_{2}$ & 138.16 & Antimicrobial [28] & Benzofuran \\
\hline 12 & 11.29 & 0.11 & 1-Hexadecene & $\mathrm{C}_{16} \mathrm{H}_{32}$ & 224.42 & $\begin{array}{l}\text { Antimicrobial, } \\
\text { antioxidant [30] }\end{array}$ & Alkenes \\
\hline 13 & 11.38 & 0.49 & Hexadecane & $\mathrm{C}_{16} \mathrm{H}_{34}$ & 226.44 & Antimicrobial cytotoxic [31] & Alkanes \\
\hline 14 & 11.78 & 0.12 & Apiol & $\mathrm{C}_{12} \mathrm{H}_{14} \mathrm{O}_{2}$ & 222.23 & Antiproliferative activity [32] & Phenylpropene \\
\hline 15 & 12.18 & 0.18 & $\alpha$-Cadinol & $\mathrm{C}_{15} \mathrm{H}_{26} \mathrm{O}$ & 222.37 & $\begin{array}{l}\text { Antifungal, hepatoprotective, } \\
\text { anti TB [28] }\end{array}$ & Sesquiterpenoids \\
\hline 16 & 12.23 & 0.19 & Ar-tumerone & $\mathrm{C}_{15} \mathrm{H}_{20} \mathrm{O}$ & 216.32 & Antimicrobial [28] & Sesquiterpenoids \\
\hline 17 & 12.28 & 0.1 & Tumerone & $\mathrm{C}_{15} \mathrm{H}_{20} \mathrm{O}$ & 216.32 & Antimicrobial [33] & Sesquiterpenoids \\
\hline 18 & 12.49 & 0.09 & Heptadecane & $\mathrm{C}_{17} \mathrm{H}_{36}$ & 240.17 & Antibacterial [27] & Alkanes \\
\hline 19 & 12.64 & 0.07 & Curlone & $\mathrm{C}_{15} \mathrm{H}_{22} \mathrm{O}$ & 218.33 & Antimicrobial, cytotoxic [34] & Sesquiterpenoids \\
\hline 20 & 13.18 & 0.1 & Tetradecanoic acid & $\mathrm{C}_{14} \mathrm{H}_{28} \mathrm{O}_{2}$ & 228.38 & $\begin{array}{l}\text { Nematicide, antifungal, } \\
\text { cancer preventive, } \\
\text { antioxidant [28] }\end{array}$ & Fatty Acids \\
\hline 21 & 13.36 & 0.11 & Benzyl Benzoate & $\mathrm{C}_{14} \mathrm{H}_{12} \mathrm{O}_{2}$ & 212.25 & Antibacterial [28] & Esters \\
\hline 22 & 13.51 & 0.35 & 1-Octadecene & $\mathrm{C}_{18} \mathrm{H}_{36}$ & 252.5 & Antimicrobial, anticancer [35] & Alkenes \\
\hline 23 & 13.59 & 0.58 & Octadecane & $\mathrm{C}_{18} \mathrm{H}_{38}$ & 254.49 & Antimicrobial [36] & Alkanes \\
\hline 24 & 13.71 & 0.1 & E-15-Heptadecenal & $\mathrm{C}_{17} \mathrm{H}_{32} \mathrm{O}$ & 252.4 & Antimicrobial [28] & Aldehydes \\
\hline 25 & 13.88 & 0.17 & $\begin{array}{l}\text { Pentadecanoic acid, } \\
\text { methyl ester }\end{array}$ & $\mathrm{C}_{16} \mathrm{H}_{32} \mathrm{O}_{2}$ & 256.42 & Antibacterial [28] & Fatty Acid Esters \\
\hline
\end{tabular}


Table 3. Cont.

\begin{tabular}{|c|c|c|c|c|c|c|c|}
\hline $\begin{array}{l}\text { Sr. } \\
\text { No. }\end{array}$ & R.T. & $\begin{array}{c}\% \\
\text { Area }\end{array}$ & Compound Name & M.F. & M.W. & Pharm. Activity & Class \\
\hline 26 & 14.46 & 0.12 & $\begin{array}{c}1,2- \\
\text { Benzenedicarboxylic } \\
\text { acid, } \\
\text { bis(trimethylsilyl) } \\
\text { ester }\end{array}$ & $\mathrm{C}_{14} \mathrm{H}_{22} \mathrm{O}_{4} \mathrm{Si}_{2}$ & 310.49 & Antimicrobial [37] & $\begin{array}{c}\text { Aromatic } \\
\text { Dicarboxylic acid } \\
\text { Esters }\end{array}$ \\
\hline 27 & 14.51 & 0.13 & $\begin{array}{l}\text { 1,8-Nonadiene, } \\
\text { 2,7-dimethyl-5- } \\
\text { (methylethenyl) }\end{array}$ & $\mathrm{C}_{14} \mathrm{H}_{24}$ & 192.34 & - & Alkenes \\
\hline 28 & 15.09 & 2.69 & $\begin{array}{l}\text { Methyl 14- } \\
\text { methylpentadecanoate }\end{array}$ & $\mathrm{C}_{17} \mathrm{H}_{34} \mathrm{O}_{2}$ & 270.5 & Antifungal [28] & Esters \\
\hline 29 & 15.36 & 0.32 & $\begin{array}{l}\text { Benzenepropanoic } \\
\text { acid, 3,5-bis(1,1- } \\
\text { dimethylethyl)-4- } \\
\text { hydroxy-, methyl } \\
\text { ester }\end{array}$ & $\mathrm{C}_{18} \mathrm{H}_{28} \mathrm{O}_{3}$ & 292.41 & $\begin{array}{l}\text { Antiandrogenic, antifungal, } \\
\text { antioxidant [38] }\end{array}$ & Esters \\
\hline 30 & 15.72 & 6.22 & $\begin{array}{l}n \text {-Hexadecanoic } \\
\text { acid }\end{array}$ & $\mathrm{C}_{16} \mathrm{H}_{32} \mathrm{O}_{2}$ & 256.4 & $\begin{array}{c}\text { Antioxidant, } \\
\text { hypocholesterolemic } \\
\text { nematicide [28] }\end{array}$ & Fatty Acids \\
\hline 31 & 15.91 & 0.96 & 5-Eicosene, (E)- & $\mathrm{C}_{20} \mathrm{H}_{40}$ & 280.5 & $\begin{array}{c}\text { Antimicrobial, cytotoxic, } \\
\text { antihyperglycemic, } \\
\text { antioxidant, insecticidal [39] }\end{array}$ & Alkenes \\
\hline 32 & 15.99 & 0.73 & Eicosane & $\mathrm{C}_{20} \mathrm{H}_{42}$ & 282.5 & Anticancer [35] & Alkanes \\
\hline 33 & 16.34 & 0.21 & $\begin{array}{l}\text { Methyl 14- } \\
\text { methylhexadecanoate }\end{array}$ & $\mathrm{C}_{18} \mathrm{H}_{36} \mathrm{O}_{2}$ & 284.5 & $\begin{array}{c}\text { Antioxidant, } \\
\text { hypocholesterolemic } \\
\text { nematicide [28] }\end{array}$ & Fatty Acid Esters \\
\hline 34 & 16.88 & 0.52 & $\begin{array}{l}\text { Heptadecanoic } \\
\text { acid }\end{array}$ & $\mathrm{C}_{17} \mathrm{H}_{34} \mathrm{O}_{2}$ & 270.5 & Antioxidant [40] & Fatty Acids \\
\hline 35 & 17.31 & 3.73 & $\begin{array}{l}9,12- \\
\text { Octadecadienoic } \\
\text { acid, methyl ester }\end{array}$ & $\mathrm{C}_{19} \mathrm{H}_{34} \mathrm{O}_{2}$ & 294.5 & $\begin{array}{c}\text { Anti-inflammatory, } \\
\text { hypocholesterolemic, cancer } \\
\text { preventive, antiarthritic, } \\
\text { antihistaminic [41] }\end{array}$ & Fatty Acid Esters \\
\hline 36 & 17.41 & 2.96 & $\begin{array}{l}9,12,15- \\
\text { Octadecatrienoic } \\
\text { acid, methyl ester }\end{array}$ & $\mathrm{C}_{19} \mathrm{H}_{32} \mathrm{O}_{2}$ & 292.5 & Antimicrobial [42] & Fatty Acid Esters \\
\hline 37 & 17.55 & 1.69 & Phytol & $\mathrm{C}_{20} \mathrm{H}_{40} \mathrm{O}$ & 204.36 & $\begin{array}{l}\text { Precursor for vitamin } \mathrm{E} \text { and } \mathrm{K}, \\
\text { antioxidant, protrctive agent } \\
\text { against breast cancer [24] }\end{array}$ & $\begin{array}{c}\text { Acyclic } \\
\text { Diterpenoids }\end{array}$ \\
\hline 38 & 17.7 & 0.61 & $\begin{array}{l}\text { Octadecanoic acid, } \\
\text { methyl ester }\end{array}$ & $\mathrm{C}_{19} \mathrm{H}_{38} \mathrm{O}_{2}$ & 298.5 & Antimicrobial [42] & Fatty Acid Esters \\
\hline 39 & 18.48 & 2.82 & Octadecanoic acid & $\mathrm{C}_{18} \mathrm{H}_{34} \mathrm{O}_{2}$ & 282.5 & Antimicrobial [28] & Fatty Acids \\
\hline 40 & 18.63 & 1.16 & 1-Docosene & $\mathrm{C}_{22} \mathrm{H}_{44}$ & 308.6 & Antibacterial [43] & Alkenes \\
\hline 41 & 20.5 & 0.43 & Triazophos & $\mathrm{C}_{12} \mathrm{H}_{16} \mathrm{~N}_{3} \mathrm{O}_{3} \mathrm{PS}$ & 313.31 & Insecticides [44] & Organophosphate \\
\hline 42 & 21.47 & 0.95 & Cyclotetracosane & $\mathrm{C}_{24} \mathrm{H}_{48}$ & 336.6 & $\begin{array}{l}\text { Antimicrobial, anticancer } \\
\text { antioxidant [28] }\end{array}$ & Cyclo Alkanes \\
\hline 43 & 21.87 & 0.08 & Tetracosane & $\mathrm{C}_{24} \mathrm{H}_{50}$ & 338.6 & $\begin{array}{c}\text { Inhibitor of } \beta \text {-amyloid } \\
\text { aggregation [28] }\end{array}$ & Alkanes \\
\hline 44 & 23.8 & 8.67 & $\begin{array}{l}1,2- \\
\text { Benzenedicarboxylic } \\
\text { acid, monophenyl } \\
\text { ester, sodium salt }\end{array}$ & $\mathrm{C}_{14} \mathrm{H}_{9} \mathrm{NaO}_{4}$ & 264.21 & COX-2 inhibitor [45] & Sodium Salt \\
\hline
\end{tabular}


Table 3. Cont.

\begin{tabular}{|c|c|c|c|c|c|c|c|}
\hline $\begin{array}{l}\text { Sr. } \\
\text { No. }\end{array}$ & R.T. & $\begin{array}{c}\% \\
\text { Area }\end{array}$ & Compound Name & M.F. & M.W. & Pharm. Activity & Class \\
\hline 45 & 25.77 & 5.1 & $\begin{array}{l}\text { 9,12- } \\
\text { Octadecadienoic } \\
\text { acid }\end{array}$ & $\mathrm{C}_{18} \mathrm{H}_{32} \mathrm{O}_{2}$ & 280.4 & Anticancer [24] & Fatty Acids \\
\hline 46 & 27.1 & 0.81 & Cyclooctacosane & $\mathrm{C}_{28} \mathrm{H}_{56}$ & 392.7 & $\begin{array}{l}\text { Antibacterial after } \\
\text { derivatization [46] }\end{array}$ & Cyclo Alkanes \\
\hline 47 & 27.58 & 0.47 & $\begin{array}{c}\text { 2,6,10,14,18,22- } \\
\text { Tetracosahexaene }\end{array}$ & $\mathrm{C}_{24} \mathrm{H}_{38}$ & 326.6 & $\begin{array}{l}\text { For dermatological } \\
\text { problem [47] }\end{array}$ & Alkenes \\
\hline 48 & 28.5 & 0.18 & Cholesta-3,5-diene & $\mathrm{C}_{27} \mathrm{H}_{44}$ & 368.6 & Cytotoxic activity [48] & Phenantherenes \\
\hline 49 & 29.58 & 0.14 & $\begin{array}{l}\text { N-hydroxy-N'-[2- } \\
\text { (trifluoromethyl) } \\
\text { phenyl]pyridine-3- } \\
\text { carboximidamide }\end{array}$ & $\mathrm{C}_{13} \mathrm{H}_{10} \mathrm{~F}_{3} \mathrm{~N}_{3} \mathrm{O}$ & 281.23 & Anti-inflammatory [28] & Carboximidamides \\
\hline 50 & 29.79 & 0.7 & 1-Nonadecene & $\mathrm{C}_{19} \mathrm{H}_{38}$ & 266.5 & $\begin{array}{l}\text { Antimicrobial, artificial } \\
\text { ripening of fruit [49] }\end{array}$ & Alkenes \\
\hline 51 & 30.75 & 2.31 & $\begin{array}{l}\text { gamma- } \\
\text { Tocopherol }\end{array}$ & $\mathrm{C}_{28} \mathrm{H}_{48} \mathrm{O}_{2}$ & 416.68 & $\begin{array}{c}\text { Antidermatitic, anticancer, } \\
\text { hepatoprotective, } \\
\text { antispasmodic [28] }\end{array}$ & $\begin{array}{l}\text { Methylated } \\
\text { phenols }\end{array}$ \\
\hline
\end{tabular}

17-(1,5-

Dimethylhexyl)-

10,13-dimethyl-

$\begin{array}{llll}52 & 31.79 & 0.56 & 1,2,6,7,8,9,11,12,14 \\ 15,16,17-\text { dodecahy }\end{array}$

15,16,17-dodecahy
drocyclopenta[a]

phenanthren-3-

one

\begin{tabular}{|c|c|c|c|c|c|c|c|}
\hline 53 & 32.17 & 4.23 & Vitamin E & $\mathrm{C}_{29} \mathrm{H}_{50} \mathrm{O}_{2}$ & 430.71 & $\begin{array}{c}\text { Antidermatitic, anticancer, } \\
\text { hepatoprotective, } \\
\text { antispasmodic [28] }\end{array}$ & $\begin{array}{l}\text { Methylated } \\
\text { phenols }\end{array}$ \\
\hline 54 & 33.87 & 0.77 & Campesterol & $\mathrm{C}_{28} \mathrm{H}_{48} \mathrm{O}$ & 400.68 & $\begin{array}{c}\text { Anti-inflammatory, } \\
\text { antidiabetic, anticancer, } \\
\text { activities and cholesterol } \\
\text { lowering agent [28] }\end{array}$ & $\begin{array}{c}\text { Steroid } \\
\text { Derivatives }\end{array}$ \\
\hline 55 & 34.09 & 0.36 & $\begin{array}{l}\text { Ergost-8(14)-en- } \\
\text { 3beta-ol }\end{array}$ & $\mathrm{C}_{28} \mathrm{H}_{48} \mathrm{O}$ & 400.7 & - & $\begin{array}{c}\text { Steroid } \\
\text { Derivatives }\end{array}$ \\
\hline 56 & 34.65 & 2.1 & Stigmasterol & $\mathrm{C}_{29} \mathrm{H}_{48} \mathrm{O}$ & 412.69 & $\begin{array}{l}\text { Synthesis of progesterone, } \\
\text { androgens, estrogens [50] }\end{array}$ & Phyto Sterols \\
\hline 57 & 36.06 & 3.7 & Beta-Sitosterol & $\mathrm{C}_{29} \mathrm{H}_{50} \mathrm{O}$ & 414.71 & $\begin{array}{l}\text { Analgesic, anti-inflammatory, } \\
\text { and antioxidant [51] }\end{array}$ & Phyto Sterols \\
\hline 58 & 36.44 & 0.23 & $\begin{array}{l}\text { Lanost-8-en-3-ol, } \\
\text { (3.beta)- }\end{array}$ & $\mathrm{C}_{32} \mathrm{H}_{54} \mathrm{O}_{2}$ & 470.8 & Antibacterial [28] & Phenantherenes \\
\hline 59 & 37.33 & 0.44 & $\begin{array}{c}\text { Pyridine-3- } \\
\text { carboxamidoxime }\end{array}$ & $\mathrm{C}_{6} \mathrm{H}_{7} \mathrm{~N}_{3} \mathrm{O}$ & 137.4 & Anti-inflammatory [52] & Carboximidamides \\
\hline 60 & 37.86 & 0.04 & $\begin{array}{l}\text { 9,19-Cyclolanost- } \\
\text { 24-en-3-ol, acetate, } \\
\text { (3beta)- }\end{array}$ & $\mathrm{C}_{32} \mathrm{H}_{52} \mathrm{O}_{2}$ & 468.8 & Anti HIV [53] & Aromatic Esters \\
\hline
\end{tabular}




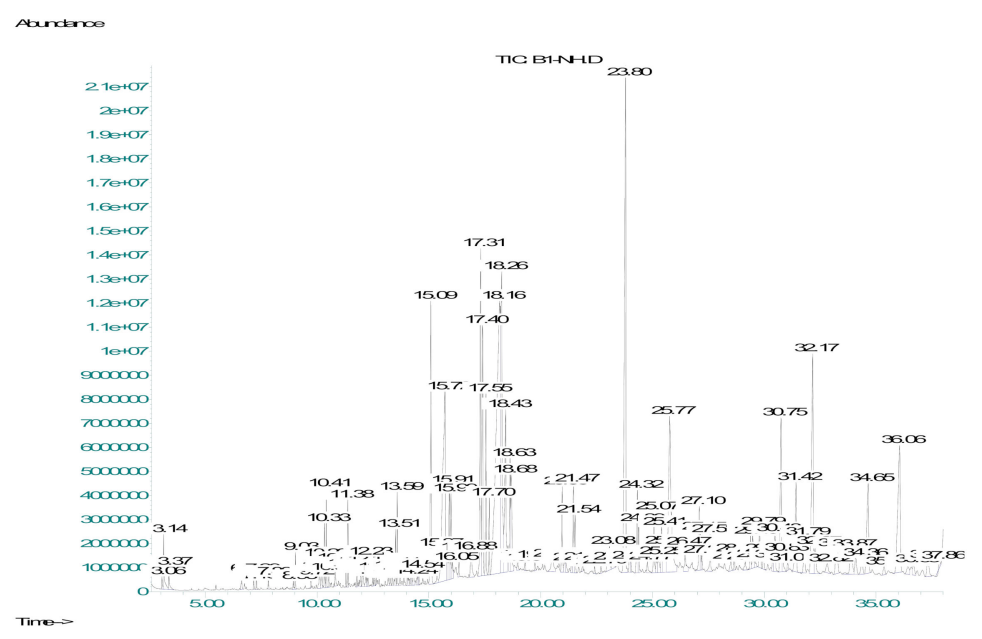

Figure 2. GC-MS chromatogram of the $n$-hexane fraction in Dracaena reflexa.

\subsection{In Vitro Biological Activities}

The biological activities of extract/fractions of Dracaena reflexa were evaluated by conducting antioxidant assays, and investigating the enzyme inhibition activities and the thrombolytic and antibacterial potential of Dracaena reflexa.

\subsubsection{Antioxidant Assays}

Radical Scavenging Activity (mg TE/g Extract)

The scavenging potential determined by the DPPH and ABTS methods was ordered as follows (Figure 3 and Table 2): $n$-butanol fraction (DRBF) $>$ chloroform fraction $(\mathrm{DRCF})>$ methanolic extract $(\mathrm{DRME})>n$-hexane fraction $(\mathrm{DRHF})$. The scavenging potential determined by the DPPH method of DRBF was $102.66 \pm 2.55 \mathrm{mg}$ TE/g extract while DRHF was $55.61 \pm 0.94 \mathrm{mg}$ TE/g extract. The maximum antioxidant potential determined by the ABTS method of DRBF was $82.50 \pm 0.37 \mathrm{mg}$ TE/g extract and the minimum ABTS results were found for DRHF, with a value of $39.22 \pm 0.56 \mathrm{mg}$ TE/g extract (Figure 3 and Table 2).
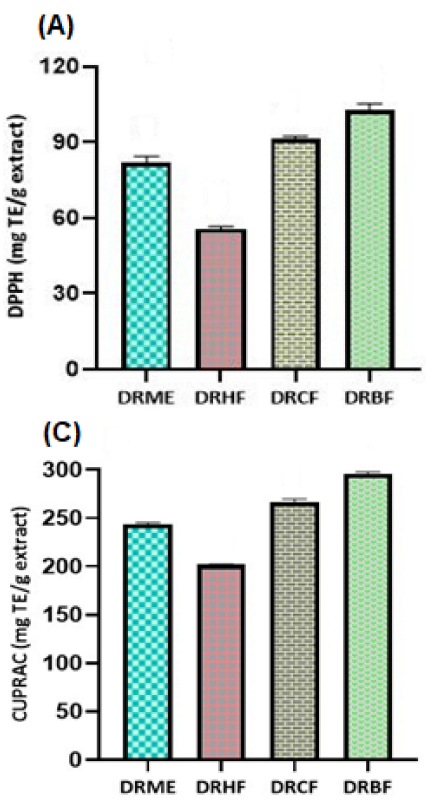

(B)

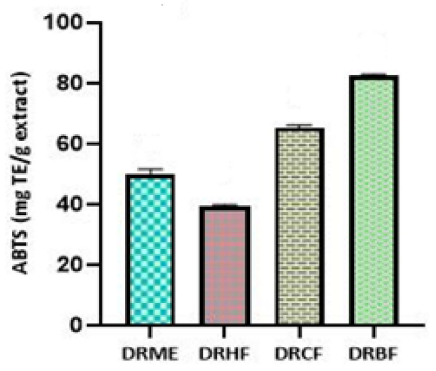

(D)

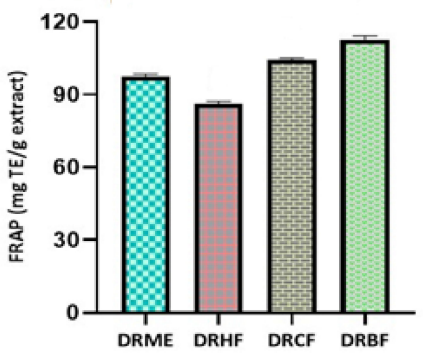

Figure 3. (A) 1,1-diphenyl-2-picrylhydrazyl (DPPH) and (B) 2,2-azinobis 3-ethylbenzothiazoline-6sulfonic acid (ABTS); (C) cupric-reducing antioxidant capacity (CUPRAC) and (D) ferric-reducing antioxidant power (FRAP) of D. reflexa extract/fractions. DRME: methanolic extract; DRHF: $n$-hexane fraction; DRCF: chloroform fraction; and DRBF: $n$-butanol fraction. 
Reducing Power Assays (mg TE/g Extract)

The reducing potential of the extract/fractions determined by CUPRAC and FRAP was ordered as follows (Figure 3 and Table 2): $n$-butanol fraction (DRBF) $>$ chloroform fraction $(\mathrm{DRCF})>$ methanolic extract $(\mathrm{DRME})>n$-hexane fraction (DRHF). The maximum reducing potential determined by DRBF and by CUPRAC and FRAP was $295.85 \pm 1.43$ and $112.42 \pm 1.86 \mathrm{mg} \mathrm{TE} / \mathrm{g}$ extract, respectively, while the minimum reducing potential of DRHF determined by CUPRAC and FRAP was $201.80 \pm 0.82$ and $86.04 \pm 1.24 \mathrm{mg}$ TE/g extract, respectively.

\subsubsection{Enzyme Inhibition Assays}

Tyrosinase Inhibition Assay (\%Age Inhibition)

The tyrosinase inhibition assay of different fractions of Dracaena reflexa was determined by spectrophotometry as described in the literature with some modifications. The assay was conducted using L-DOPA ( $\geq 98 \%$ Sigma-Aldrich, Saint Louis, MO, USA) as a substrate. The tyrosinase inhibition activity of different fractions was expressed as the $\%$ inhibition of the enzyme. The \% inhibition of different fractions was ordered as follows: $n$-butanol fraction $(\mathrm{DRBF})>$ methanolic extract $(\mathrm{DRME})>$ chloroform fraction $(\mathrm{DRCF})>n$-hexane fraction (DRHF). The tyrosinase inhibition potential of DRBF and DRME was observed to be $73.46 \%$ and $72.79 \%$, respectively, which is comparable to the inhibition of kojic acid (83.12\%). The \% age tyrosinase inhibition activity for extract/fractions of Dracaena reflexa was in the range of $61.66-73.46 \%$ (Table S1). These results show the potential efficiency of Dracaena reflexa as an inhibitor of tyrosinase enzyme (Figure 4).

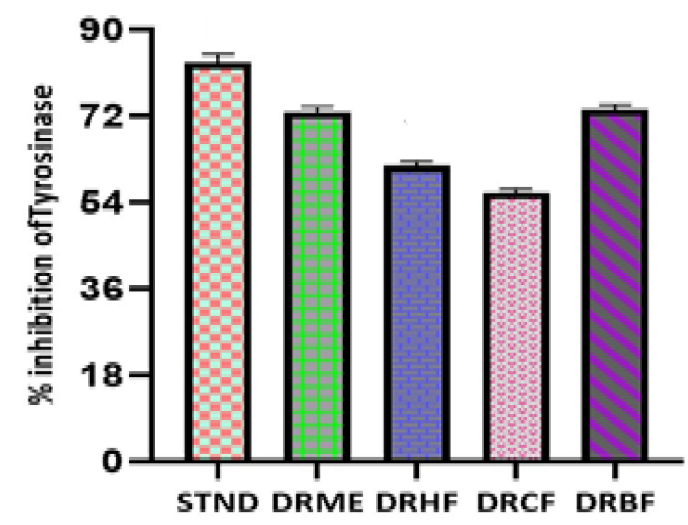

Figure 4. Tyrosinase inhibition of kojic acid (standard) and extract/fractions of Dracaena reflexa. STND: kojic acid (Standard); DRME: methanolic extract; DRHF: $n$-hexane fraction; DRCF: chloroform fraction; and DRBF: $n$-butanol fraction.

Acetylcholinesterase (AChE) and Butyrylcholinesterase (BChE) Inhibition Activity (\%Age Inhibition)

The results were expressed as thee $\%$ inhibition of enzymes \pm standard deviation. The AChE inhibition results of the extract/fractions were ordered as follows (Figure 5): $n$-butanol fraction $(\mathrm{DRBF})>$ methanolic extract $(\mathrm{DRME})>n$-hexane fraction $(\mathrm{DRHF})>$ chloroform fraction (DRCF). The \% age acetylcholinesterase inhibition activity of the extract/fractions of Dracaena reflexa was in the range of 40.47-64.06\% (Table S2).

The \% inhibition of DRBF was observed to be $64.06 \pm 2.65$ (\% inhibition), which was nearly equal to the \% inhibition of galantamine of $82.58 \pm 1.58$ (used as standard).

The BChE inhibition results of different fractions were ordered as follows (Figure 5): methanolic extract $(\mathrm{DRME})>n$-butanol fraction $(\mathrm{DRBF})>n$-hexane fraction $(\mathrm{DRHF})>$ chloroform fraction (DRCF). The \% inhibition of BChE of DRME was calculated as $50.97 \pm 0.57$ (\% inhibition) while that of DRCF was $38.67 \pm 2.57$ (\% inhibition). The $\%$ age butyrylcholinesterase inhibition activity for extract/fractions of Dracaena reflexa was in the range of $38.67-50.97 \%$ (Table S2). 
(A)

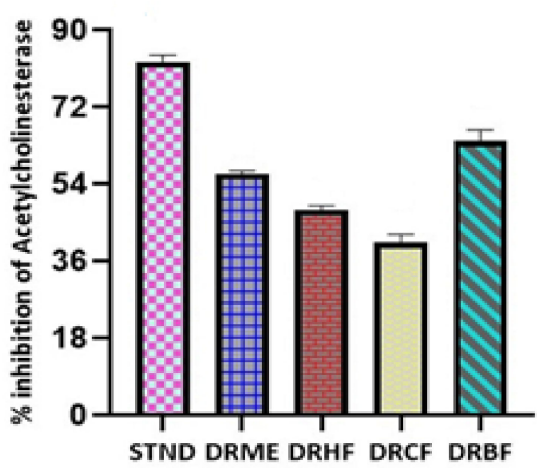

(B)

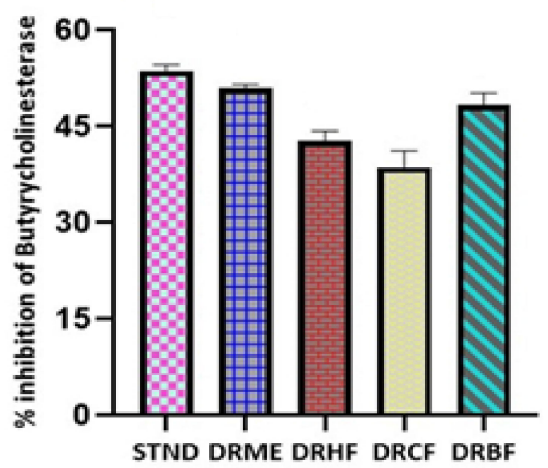

Figure 5. (A) Acetylcholinesterase inhibition of galantamine (standard) and extract/fractions and (B) butyrylcholinesterase inhibition of galantamine (standard) and extract/fractions of Dracaena reflexa. STND: galantamine (Standard); DRME: methanolic extract; DRHF: $n$-hexane fraction; DRCF: chloroform fraction; and DRBF: $n$-butanol fraction.

\subsubsection{Thrombolytic Activity}

Streptokinase (positive control) showed significant clot lysis activity while water (negative control) showed minimal clot lysis activity. The \% age thrombolytic activity of the extract/fractions of Dracaena reflexa was in the range of $55.21-76.06 \%$ (Table 4).

Table 4. Thrombolytic activity of the extract/fractions of D. reflexa and streptokinase in five blood samples.

\begin{tabular}{cccccc}
\hline $\begin{array}{c}\text { Sample } \\
\text { Name }\end{array}$ & $\begin{array}{c}\text { Blood } \\
\text { Sample 1 }\end{array}$ & $\begin{array}{c}\text { Blood } \\
\text { Sample 2 }\end{array}$ & $\begin{array}{c}\text { Blood } \\
\text { Sample 3 }\end{array}$ & $\begin{array}{c}\text { Blood } \\
\text { Sample 4 }\end{array}$ & $\begin{array}{c}\text { Blood } \\
\text { Sample 5 }\end{array}$ \\
\hline DRME & $72.67 \pm 1.06$ & $73.69 \pm 0.55$ & $74.43 \pm 0.63$ & $73.34 \pm 0.99$ & $71.51 \pm 2.75$ \\
DRHF & $57.78 \pm 0.61$ & $57.59 \pm 0.99$ & $55.21 \pm 4.17$ & $56.22 \pm 1.85$ & $57.16 \pm 1.04$ \\
DRCF & $74.11 \pm 0.61$ & $74.14 \pm 1.46$ & $76.06 \pm 1.92$ & $72.97 \pm 2.94$ & $72.54 \pm 1.17$ \\
DRBF & $67.60 \pm 0.72$ & $66.58 \pm 1.02$ & $69.37 \pm 0.77$ & $65.89 \pm 2.53$ & $67.61 \pm 2.74$ \\
Streptokinase & $84.81 \pm 0.311$ & $85.35 \pm 0.911$ & $85.4 \pm 1.53$ & $83.36 \pm 3.32$ & $84.42 \pm 3.03$ \\
\hline
\end{tabular}

DRME: methanolic extract; DRHF: $n$-hexane fraction; DRCF: chloroform fraction; and DRBF: $n$-butanol fraction.

\subsubsection{Antibacterial Activity of $n$-Hexane Fraction}

Numerous antibacterial compounds were tentatively identified in the $n$-hexane fraction of D. refelxa by GC-MS analysis. Eight bacterial strains (Bacillus subtilis ATCC1692, Micrococcus luteus ATCC 4925, Staphylococcus epidermidis ATCC 8724, Bacillus pumilus ATCC 13835, Staphylococcus aureus ATCC 6538, Escherichia coli ATCC 25922, Bordetella bronchiseptica ATCC 7319, and Pseudomonas aeruginosa ATCC 9027) were used for evaluation of the antibacterial potential of $n$-hexane fraction and co-amoxiclav (amoxicillinclavulanic acid) was used as a standard antibacterial agent.

The $n$-hexane fraction at a concentration of $20 \mathrm{mg} / \mathrm{mL}$ showed a maximum zone of inhibition $(23 \mathrm{~mm}$ ) against Bacillus pumilus and at a concentration of $20 \mathrm{mg} / \mathrm{mL}$, minimum activity $(13 \mathrm{~mm})$ was observed for Bordetella bronchiseptica. The $n$-hexane fraction at a concentration of $5 \mathrm{mg} / \mathrm{mL}$ was least active against some strains and not effective against most of the tested strains. These results revealed the direct relationship between the concentration and antibacterial activity of the fraction (Figure S1). The detailed antibacterial activity of the $n$-hexane fraction is depicted in Table 5 . 
Table 5. Antibacterial activity of $n$-hexane fraction of Dracaena reflexa.

\begin{tabular}{|c|c|c|c|c|}
\hline Strain Name & $\begin{array}{c}\text { Zone of Inhibition } \\
\text { (mm) of Standard } \\
\text { (Co-Amoxiclav) } \\
\text { (Conc. } 1 \mathrm{mg} / \mathrm{mL} \text { ) }\end{array}$ & MIC (mg/mL) & $\begin{array}{l}\text { Conc. }(\mathrm{mg} / \mathrm{mL}) \\
\text { of Fraction }\end{array}$ & $\begin{array}{c}\text { Zone of } \\
\text { Inhibition of } \\
\text { DRHF (mm) }\end{array}$ \\
\hline \multirow{3}{*}{ Bacillus Subtilis } & \multirow{3}{*}{21} & \multirow{3}{*}{4} & 5 & 4 \\
\hline & & & 10 & 12 \\
\hline & & & 20 & 19 \\
\hline \multirow{3}{*}{$\begin{array}{c}\text { Micrococcus } \\
\text { luteus }\end{array}$} & \multirow{3}{*}{23} & \multirow{3}{*}{3} & 5 & 5 \\
\hline & & & 10 & 11 \\
\hline & & & 20 & 16 \\
\hline \multirow{3}{*}{$\begin{array}{l}\text { Staphylococcus } \\
\text { epidermidis }\end{array}$} & \multirow{3}{*}{25} & \multirow{3}{*}{8} & 5 & NA \\
\hline & & & 10 & 11 \\
\hline & & & 20 & 20 \\
\hline \multirow{3}{*}{ Bacillus pumilus } & \multirow{3}{*}{24} & \multirow{3}{*}{5} & 5 & 8 \\
\hline & & & 10 & 14 \\
\hline & & & 20 & 23 \\
\hline \multirow{3}{*}{$\begin{array}{c}\text { Staphylococcus } \\
\text { aureus }\end{array}$} & \multirow{3}{*}{21} & \multirow{3}{*}{6} & 5 & NA \\
\hline & & & 10 & 10 \\
\hline & & & 20 & 17 \\
\hline \multirow{3}{*}{ Escherichia coli } & \multirow{3}{*}{22} & \multirow{3}{*}{3} & 5 & 5 \\
\hline & & & 10 & 9 \\
\hline & & & 20 & 15 \\
\hline \multirow{3}{*}{$\begin{array}{c}\text { Bordetella } \\
\text { bronchiseptica }\end{array}$} & \multirow{3}{*}{25} & \multirow{3}{*}{6} & 5 & NA \\
\hline & & & 10 & 8 \\
\hline & & & 20 & 13 \\
\hline \multirow{3}{*}{$\begin{array}{c}\text { Pseudomonas } \\
\text { aeruginosa }\end{array}$} & \multirow{3}{*}{ NA } & \multirow{3}{*}{8} & 5 & NA \\
\hline & & & 10 & 10 \\
\hline & & & 20 & 22 \\
\hline
\end{tabular}

MIC: minimum inhibitory concentration of the sample; NA: not observed; 5, 10, and 20: 5, 10, and $20 \mathrm{mg} / \mathrm{mL}$ fraction concentrations.

\subsection{In Silico Molecular Docking Studies}

\subsubsection{Molecular Docking for Tyrosinase Enzyme}

Molecular docking studies were performed for tyrosinase receptors. To estimate the binding affinities and binding interactions at the active sites, molecular docking of four major compounds identified by GC-MS [54], beta-sitosterol, 9,12-octadecadienoic acid, octadecatrienoic acid, methyl ester, vitamin $C$ and standard kojic acid with tyrosinase target enzyme was performed (Figures 6 and 7 , and Table 6 ). The binding affinity of betasitosterol (-9.2) was nearly 2 -fold higher than the binding affinity of kojic acid ( -4.80$)$. This study was validated by redocking of tyrosinase and selected ligands with Autodock-1.5.6. Moreover, the same results were obtained in terms of the binding affinity and RMSD values. This reveals the potent role of Dracaena reflexa in tyrosinase inhibition. Detailed tables showing the binding affinities and bonding forces of ligands and enzymes are given in the Supplementary Materials (Table S3 and Figure S2). 


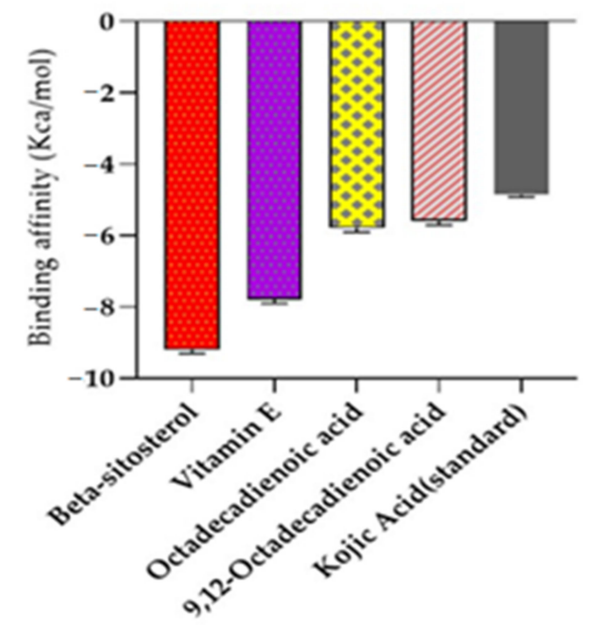

Figure 6. The binding affinity of kojic acid, beta-sitosterol, octadecadienoic acid, octadecatrienoic acid methyl ester, and vitamin $\mathrm{E}$ with tyrosinase enzyme.

(A)

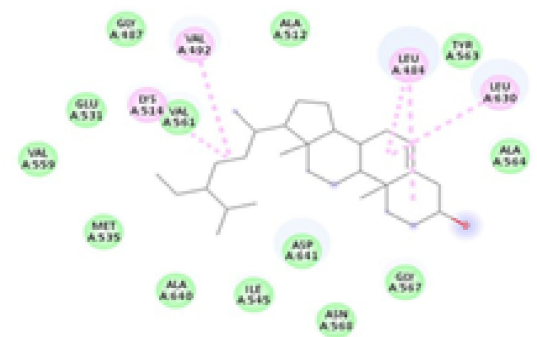

(B)

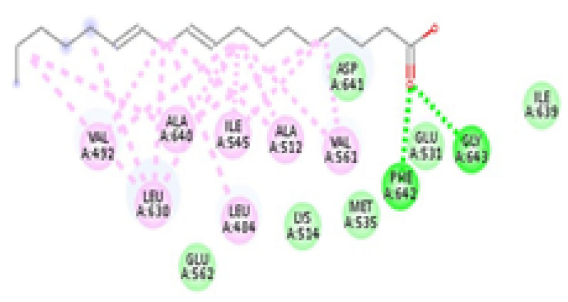

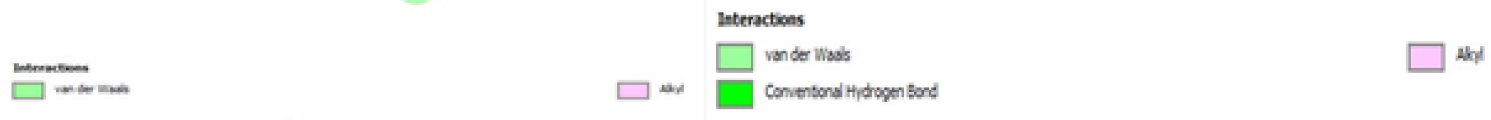

(C)

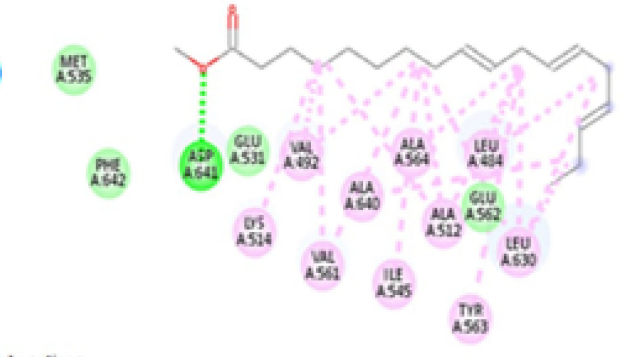

(D)

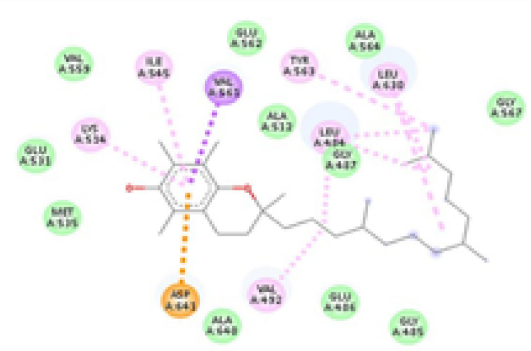

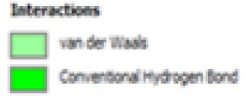
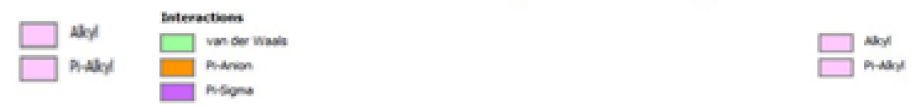

(E)

$$
\text { MET }
$$

A:735

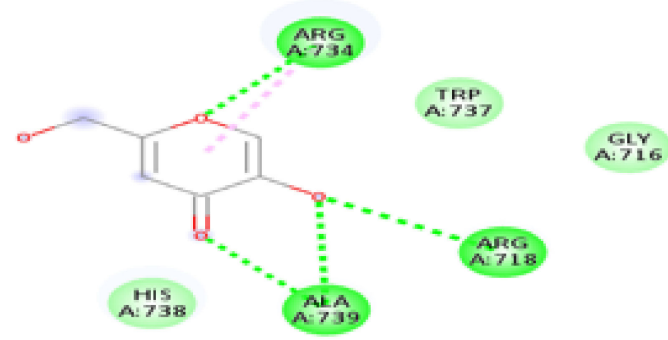

$\square$ vin der wals

Figure 7. Interaction of tyrosinase and ligands. (A) Beta-sitosterol, (B) 9,12-octadecadienoic acid, (C) octadecatrienoic acid, methyl ester, (D) vitamin C, and (E) kojic acid. 
Table 6. Binding affinity of ligands and acetylcholinesterase and butylcholinesterase.

\begin{tabular}{ccc}
\hline Ligand Name & Binding Affinity for AChE & Binding Affinity for BChE \\
\hline Alpha-Cadinol & -7.8 & -8.2 \\
n-Hexadecanoic Acid & -6.4 & -5.3 \\
N-hydroxy-N'-[2- & & -8 \\
$\begin{array}{c}\text { trifluoromethyl)phenyl]pyridine- } \\
\text { 3-carboximidamide } \\
\text { Galantamine }\end{array}$ & -9.3 & -8.8 \\
\hline
\end{tabular}

2.3.2. Molecular Docking for Acetylcholinesterase (AChE) and Butyrylcholinesterase (BChE)

Molecular docking studies were performed for both AChE (E.C. 3.1.1.7) and BChE (doi:10.2210/pdb6SAM/pdb). The three ligands were selected from the GC-MS metabolic library [54] based on the literature and similarity with the structure of the standard ligand (galantamine). The binding affinity of N-hydroxy- $\mathrm{N}^{\prime}$-[2-(trifluoromethyl)phenyl]pyridine3-carboximidamide (HTPP) with AChE and BChE ( -9.3 and -8 , respectively) was nearly equal to the binding affinity of galantamine with $\mathrm{AChE}$ and $\mathrm{BChE}(-8.2$ and -8.8 , respectively), which was used as the standard drug in the cholinesterase inhibition assay. The molecular docking study was validated by redocking of acetycholinesterase, butyrylcholinesterase, and selected ligands with Autodock-1.5.6. Moreover, the same outcomes were obtained in terms of the binding affinity and RMSD values. The docking results of the ligands with both receptors are presented in Figures 8-10, and Table 6. Detailed tables showing the binding affinities and bonding forces of ligands and enzymes are given in the Supplementary Materials (Tables S4 and S5 and Figures S3 and S4).

(A)

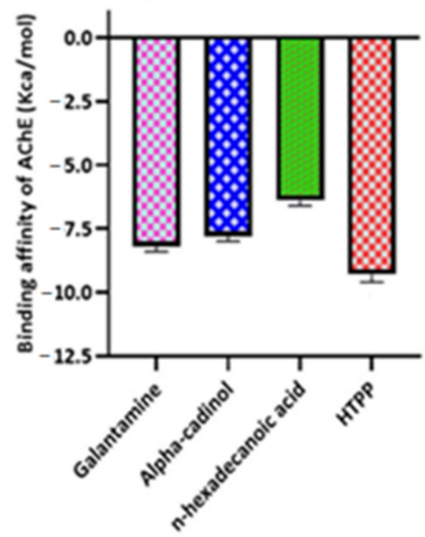

(B)

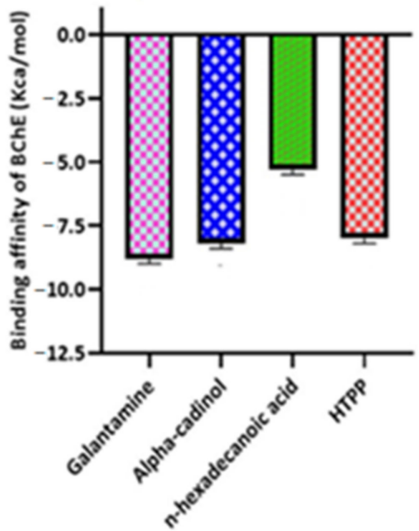

Figure 8. (A) Binding affinity of galantamine, alpha-cadinol, $n$-hexadecanoic acid, and N-hydroxy- $\mathrm{N}^{\prime}$ [2-(trifluoromethyl)phenyl]pyridine-3-carboximidamide (HTPP) with acetylcholinesterase (AChE). (B) Binding affinity of galantamine, alpha-cadinol, $n$-hexadecanoic acid, and N-hydroxy-N'-[2(trifluoromethyl)phenyl]pyridine-3-carboximidamide (HTPP) with butyrylcholinesterase (BChE). 
(B)
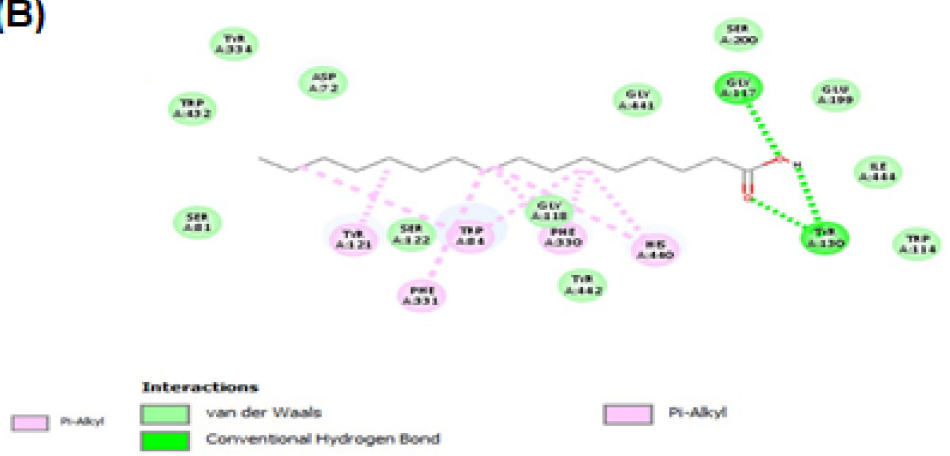

晃

(A)

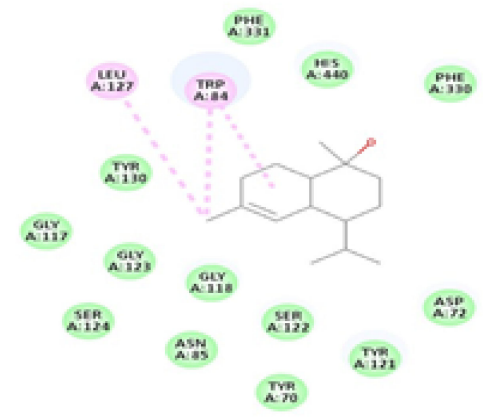

is:
(C)

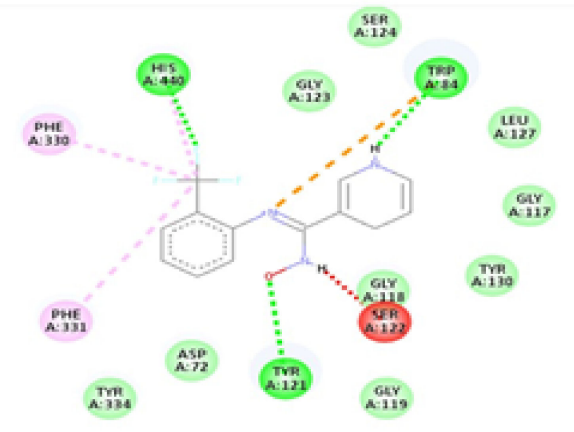

(D)
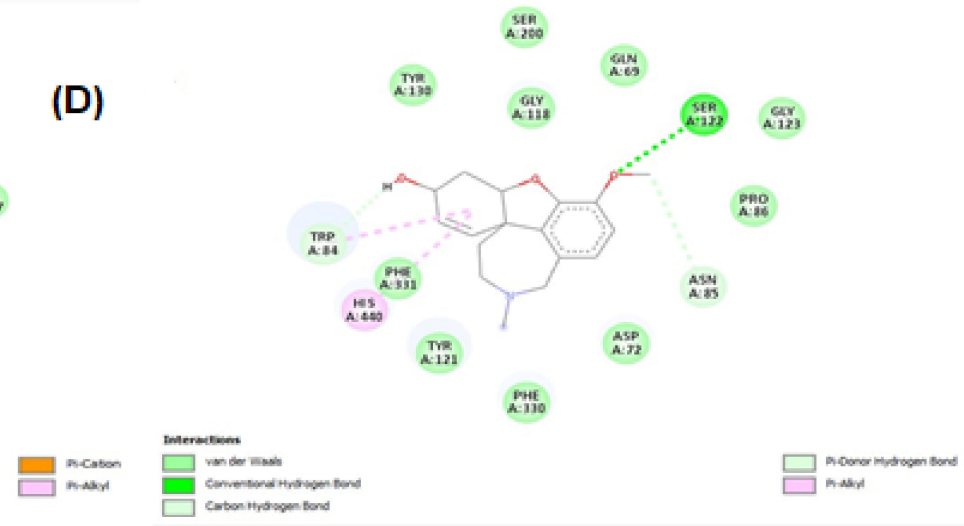

Figure 9. Interaction between acetylcholinesterase and ligands. (A) alpha-cadinol; (B) n-hexadecanoic acid; (C) N-hydroxy-N'-[2-(trifluoromethyl)phenyl]pyridine-3-carboximidamide; and (D) galantamine.
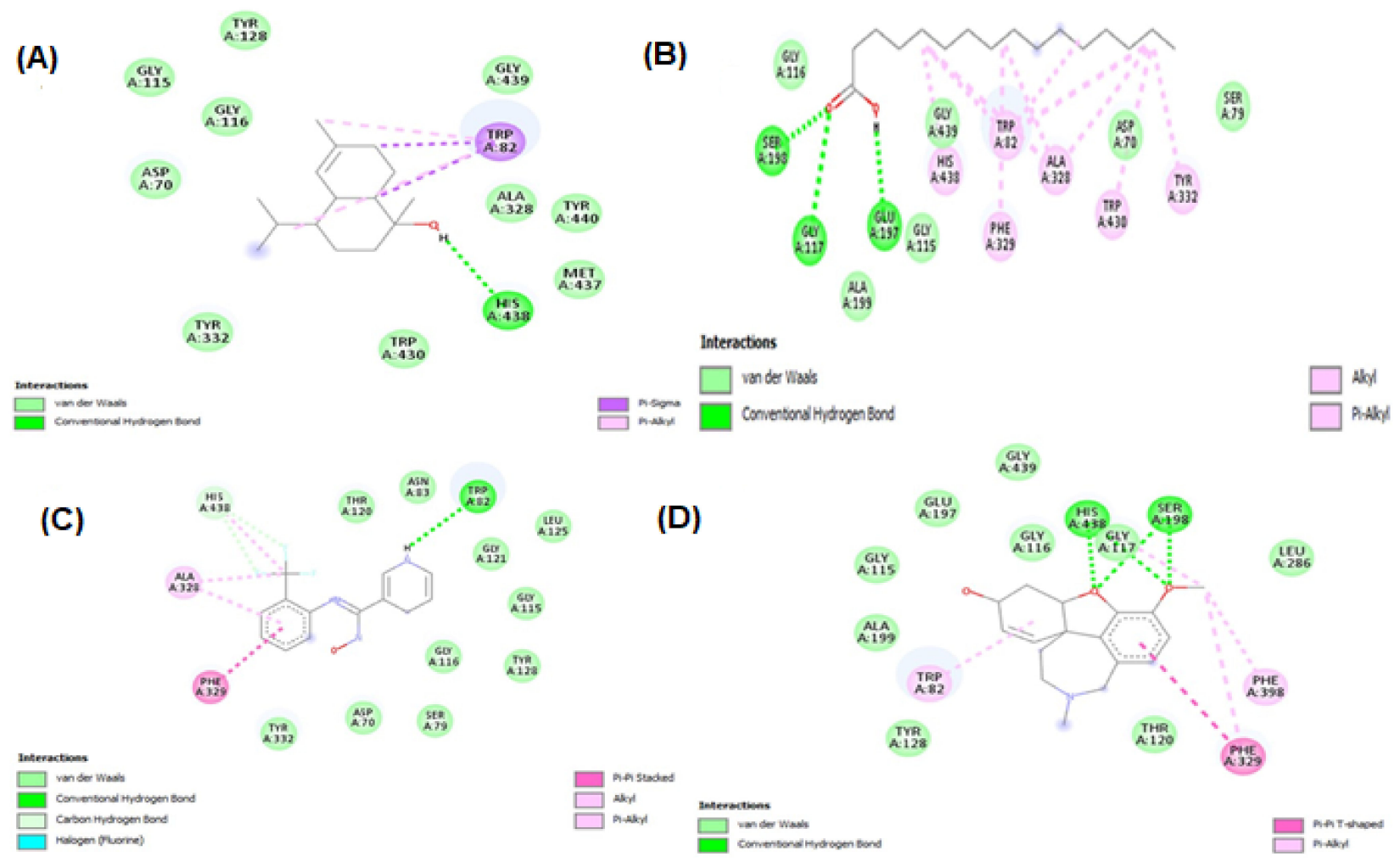

Figure 10. Interaction between butyrylcholinesterase and ligands. (A) Alpha-cadinol, (B) nhexadecanoic acid, (C) N-hydroxy-N'-[2-(trifluoromethyl)phenyl]pyridine-3-carboximidamide, and (D) galantamine. 


\section{Discussion}

The phytochemicals present in the extract/fractions of Dracaena reflexa analysis showed that extract/fractions are a rich source of alkaloids, flavonoids, phenols, saponins, glycosides, tannins, steroids, and lipids. Major constituents, such as alkaloids, contribute to analgesic and antimicrobial activity; flavonoids and tannins act as antioxidant and antibacterial agents [55]; and saponins have antibacterial, anti-inflammatory, anticancer, and anti-diabetic activities [56]. The presence of these phytochemicals in the extracts/fractions of $D$. reflexa might contribute to its therapeutic potential.

Previous analysis of the Dracaena genus indicated the presence of various phenols and flavonoids [19]. $n$-Butanol fraction showed the highest phenolic contents $(92.72 \pm 0.79 \mathrm{mg}$ $\mathrm{GAE} / \mathrm{g}$ extract) and the $n$-hexane fraction showed the minimum phenolic content (44.72 $\pm 0.79 \mathrm{mg} \mathrm{GAE} / \mathrm{g}$ extract). Previous data revealed that a methanolic extract of roots has a higher antioxidant potential than an extract of leaves [21]. These higher values may be attributed to the higher polyphenols content in roots than leaves. Therefore, the TPC values ( $88.16 \mathrm{mg}$ GAE/g extract) for methanolic extract in our study (for combined aerial parts and roots) were observed to be higher than the TPC values (49.69 mg GAE/g extract) of leaves as already reported in the literature [57]. Maximum total flavonoid contents $(110 \pm 0.83 \mathrm{mg}$ QE/g extract) were observed in the methanolic extract while minimum total flavonoid contents $(25.29 \pm 4.16 \mathrm{mg} \mathrm{QE} / \mathrm{g}$ extract) were observed in the $n$-hexane fraction. An extensive literature review of different extract/fractions of the whole plant (aerial parts and roots) of Dracaena reflexa revealed that no comprehensive scientific study has been conducted on the total phenolic and flavonoid contents so far. In the present study, the use of various fractions revealed that more polar solvents have greater potential to extract polyphenols than less polar or non-polar solvents.

Reactive oxygen species (ROS) are normally formed in the metabolic processes. Excessive accumulation of ROS has adverse effects on fatty acids, DNA, and proteins, which is responsible for tissue injury and inflammation [58]. Therefore, to enhance the immune system, these ROS should be detoxified using antioxidants. Antioxidants from synthetic sources are less favored over natural-origin antioxidants due to their adverse effects. Natural-origin antioxidants are widely distributed in many plants, which are used for many biological activities [14]. Polyphenols are biologically active constituents of plants. After the consumption of polyphenols, various effects, including antibacterial, antioxidant, antiviral, antidiabetic, and anticancer effects, are observed [59]. Flavonoid compounds are associated with the following biological effects: antioxidant, anti-inflammatory, antiallergic, and anticancer [60]. Previous data about phenolic compounds revealed a direct association with antioxidant activity [61]. To the best of our knowledge, the literature does not report on the antioxidant activity of the methanolic extract, $n$-hexane, chloroform, and $n$-butanol fractions of Dracaena reflexa from Pakistan. However, one Indian study reported the antioxidant activity of only the methanolic extract of leaves using DPPH and FRAP [57]. The results of the radical scavenging activity and reducing power assays revealed that there is a direct association with the polyphenol contents. Fractions with the highest phenolic and flavonoid contents showed significant antioxidant potential [62].

Tyrosinase has a crucial role in the biosynthesis of melanin. Excessive melanin leads to melasma and age spots due to overexpression of tyrosinase. Antioxidants and tyrosinase inhibitors are desired preservatives and skin-protecting ingredients in the cosmetics and food industry [63]. In the market, over the last couple of years, several products related to whitening purposes have been introduced, but none of these therapies have shown satisfactory results. This is usually due to the greater toxicity and the mutagenic effects of these whitening agents, such as the effects observed for hydroquinone [64]. Arbutin, kojic acid, and azelaic acid have been used as tyrosinase inhibitors in the cosmetic and pharmaceutical industry due to their capacity to reduce high melanin production; however, controversy persists concerning their effectiveness and safety [65]. The search for new natural tyrosinase inhibitors with better therapeutical activities, good skin penetration, and fewer side effects is currently continuing. Our investigations revealed an extremely 
potent inhibition of the enzyme using the methanolic extract and $n$-butanol fraction (72.79 and $73.42 \%$ inhibition, respectively) and some moderate results using the $n$-hexane and chloroform fractions (61.66 and 56.03\% inhibition, respectively) of the Dracaena reflexa plant. Such significant inhibition of tyrosinase may be attributed to the presence of some bioactive compounds as revealed by GC-MS profiling, such as beta-sitosterol and vitamin E (Figure 11), which showed siignificant binding affinity with tyrosinase enzyme, and may be due to some other compounds in these extract/fractions.

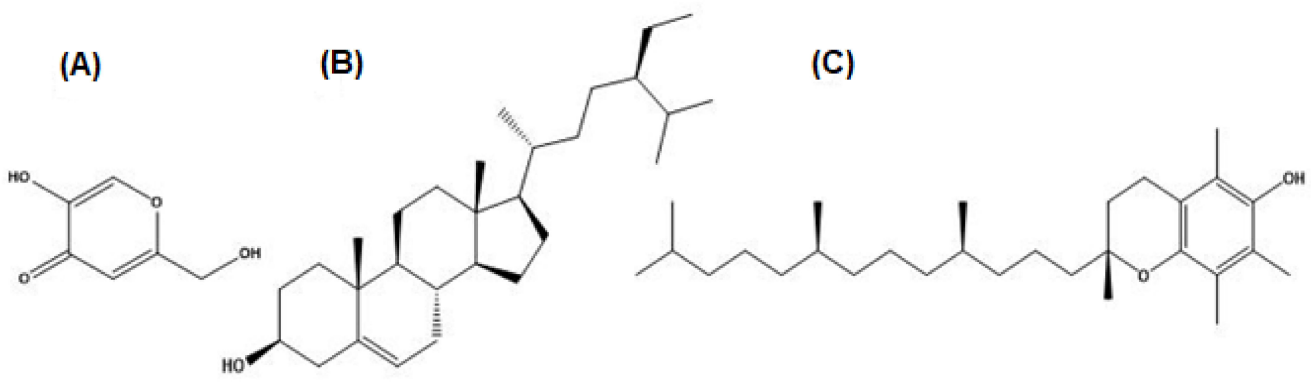

Figure 11. Structures of the GC-MS profiled compounds and kojic acid docked with tyrosinase. (A) Kojic acid, (B) beta-sitosterol, and (C) vitamin E.

The most common type of dementia is Alzheimer's disease (AD). In this regard, numerous synthetic and plant-derived cholinesterase inhibitors are ordinarily used for the management and betterment of the disease [66]. Phytomedicines have been used for the betterment of cognitive disorders and the management of memory loss. Polyphenols have the ability to decrease the occurrence of some geriatric neurological diseases, including macular degeneration and dementia [67]. Acetylcholinesterase inhibitors are used for the symptomatic management of several neurological diseases, senile dementia, ataxia, Myasthenia Gravis, Parkinson's disease, and Alzheimer's disease [68]. Several studies of various plants' acetylcholinesterase inhibitory activities have been conducted, suggesting their use to cure neurodegenerative disorders [69]. A literature review revealed that phenolic/flavonoid-rich fractions produce significant acetylcholinesterase inhibition activity [70]. DRME and DRBF with higher TPC and TFC showed better inhibition of acetylcholinesterase and butyrylcholinesterase than other fractions. The results of these extract/fractions regarding cholinesterase inhibition were comparable to the inhibition of galantamine, which was used as a standard drug in this assay. These results may be attributed to the metabolites identified by GC-MS profiling, such as alpha-cadinol and N-hydroxy-N'-[2-(trifluoromethyl)phenyl]pyridine-3-carboximidamide (Figure 12), which showed significant binding with acetylcholinesterase and butyrylcholinesterase enzymes and may be due to some other compounds in these extract/fractions. This suggests the potential of Dracaena reflexa for the management of neurological disorders.
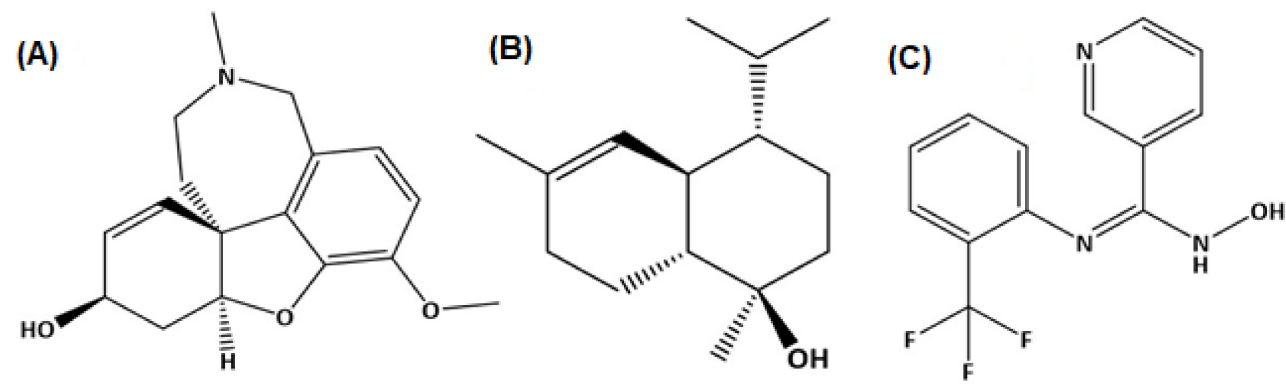

Figure 12. Structures of GC-MS profiled compounds and galanatmine docked with acetylcholinesterase and butyrylcholinesterase. (A) Galantamine, (B) alpha-cadinol, and (C) N-hydroxy-N'[2-(trifluoromethyl)phenyl]pyridine-3-carboximidamide. 
Flavonoids are responsible for antiviral, antibacterial, antiallergic, antitumor, antifungal, and antithrombotic activities [71]. An extract of D. cochinchinensis showed antithrombotic activity due to its effect on platelet aggregation and anticoagulation in a rat thrombosis and blood stasis model [72]. Methanol crude extract and carbon tetra chloride-soluble fraction of D. spicata showed mild thrombolytic activity [73]. The thrombolytic activity of DRME and DRCF was comparable to the thrombolytic activity of streptokinase, which was used as a standard drug.

The in vitro antibacterial assay of the $n$-hexane fraction of $D$. reflexa was tested against five Gram-positive and three Gram-negative pathogens. The antibacterial activity may be caused by the presence of biological compounds, namely alkaloids and phenolic and flavonoid compounds [74]. Tentative identification of the $n$-hexane fraction by GCMS revealed many compounds with antibacterial activity, namely dodecane [22], artumerone [33], heptadecane [27], benzyl benzoate [28], pentadecanoic acid, methyl ester [28], cyclooctacosane [46], and lanost-8-en-3-ol, (3.beta.)- [75]. The $n$-hexane fraction revealed a significant zone of inhibition $(>9 \mathrm{~mm})$ against most of the bacteria used in the assay. Methanolic root extract and aqueous leaf extract were previously tested against Staphylococcus aureus, Enterobacter aerogenes, Proteus vulgaris, and Lacto bacillus [21].

In silico studies have been successfully employed for the theoretical prediction of ligand-target interactions for better interpretation of the molecular basis of the biological activity of natural products. It also provides further insights into the possible mechanism of action and binding mode of active compounds against enzymes. To obtain a better insight into the inhibition ability of the studied compounds and to correlate the experimental enzyme inhibition results, four compounds from the GC-MS profile of $n$-hexane fraction (beta-Sitosterol, 9,12-octadecadienoic acid, octadecatrienoic acid, methyl ester, and vitamin E) along with kojic acid were docked against tyrosinase enzyme, and three compounds of $n$-hexane fraction (alpha-cadinol, $n$-hexadecanoic acid, and N-hydroxy$\mathrm{N}^{\prime}$-[2-(trifluoromethyl)phenyl]pyridine-3-carboximidamide) along with galantamine were docked against acetylcholinesterase and butyrylcholinesterase enzymes.

Conclusively, the in silico molecular docking results describe the interaction of tyrosinase, acetylcholinesterase, and butyrylcholinesterase with the ligands beta-sitosterol, 9,12-octadecadienoic acid, octadecatrienoic acid, methyl ester, vitamin E, alpha-cadinol, $n$-hexadecanoic acid, and N-hydroxy- $\mathrm{N}^{\prime}$-[2-(trifluoromethyl)phenyl]pyridine-3-carboximi damide found in GC-MS analysis confirm our finding of the plant extract in terms of tyrosinase, acetylcholinesterse, and butyrylcholinesterase inhibition assays.

\section{Materials and Methods}

\subsection{Sample Collection and Plant Identification}

The whole plant (aerial parts and roots) was collected in November 2020 from Kasur, Punjab, Pakistan, identified by the Herbarium Department of Botany, Faculty of Life science, The Islamia University of Bahawalpur, and the specimen was submitted to the herbarium with the reference number 153 on 27.01.2021.

\subsection{Extract Preparation and Fractionation}

Air-dried plant was macerated in aqueous alcohol with alcohol and water at a ratio of 80:20. Aqueous methanol was used as a solvent owing to its efficient extraction of phenolics and flavonoids [76]. Plant material $(7 \mathrm{~kg})$ was soaked in $20 \mathrm{~L}$ of solvent. The extract was filtered and dried at $40{ }^{\circ} \mathrm{C}$ in reduced pressure using a rotary evaporator (Heidolph, Schwabach, Germany). Furthermore, the extract was air dried to obtain solid/gummy residue. Finally, the extract was fractionated using a separating funnel with the three solvents: $n$-hexane, chloroform, and $n$-butanol, with an increasing order of polarity. Fractions were further concentrated with the help of a rotary evaporator at $40{ }^{\circ} \mathrm{C}$ and further air dried and stored for further analysis. 


\subsection{Phytochemical Analysis}

\subsubsection{Preliminary Phytochemical Analysis}

All the extract/fractions of Dracaena reflexa were analyzed for their primary and secondary metabolites to confirm the presence of various primary metabolites, such as carbohydrates, amino acids, proteins, and lipids, and secondary metabolites, such as alkaloids, tannins, phenols, flavonoids, saponins, steroids, glycosides, and resins, according to standard methods.

\subsubsection{Total Phenolic and Flavonoid Contents}

Estimation of Total Phenolic Contents (TPC)

The Folin-Ciocalteu (FC) method given in the literature [77] with slight modification was used for the estimation of the total phenolic contents in all extract/fractions of Dracaena reflexa. The dried extract/fractions were dissolved in methanol to obtain a stock solution with a concentration of $1 \mathrm{mg} / \mathrm{mL}$. Similarly, the solution of gallic acid was also prepared in methanol with concentrations of $10,20,40,80,100$, and $200 \mu \mathrm{g} / \mathrm{mL}$. The standard curve of gallic acid was drawn. A volume of $200 \mu \mathrm{L}$ of extract/fractions or standard was added to an Eppendorf tube and $200 \mu \mathrm{L}$ of FC reagent were added. The mixture was mixed under vortexing. After mixing, $0.8 \mathrm{~mL}$ of sodium carbonate were added to the solution and incubated at room temperature for $2 \mathrm{~h}$. A volume of $200 \mu \mathrm{L}$ of the mixed solution was transferred to a 96 microtiter plate and the absorbance was measured at $765 \mathrm{~nm}$ using a BioTek Synergy HT (Winooski, VT, USA) microplate reader. Gallic acid was used as the standard for the determination of the total phenolic contents. TPC was expressed in milligrams of gallic acid equivalents per gram of dry extract (mg GAE/g extract).

\section{Estimation of Total Flavonoid Contents (TFC)}

The total flavonoid contents were determined by using a method available in the literature with slight modifications [77]. The stock solution of extract/fractions was prepared in methanol $(1 \mathrm{mg} / \mathrm{mL})$. A mixture of $1 \mathrm{~mL}$ of extract/fractions solution, $4 \mathrm{~mL}$ of deionized water, $300 \mu \mathrm{L}$ of $\mathrm{NaNO}_{3}$, and $300 \mu \mathrm{L}$ of $10 \% \mathrm{AlCl}_{3}$ solution was added to the test tubes. The mixture was subjected to vortexing. Finally, $2 \mathrm{~mL}$ of $1 \mathrm{M} \mathrm{NaOH}$ solution were added to the mixture. The mixture was incubated for $6 \mathrm{~min}$ at ambient temperature. A volume of $2.4 \mathrm{~mL}$ of deionized water was added to the incubated mixture solution. By placing $200 \mu \mathrm{L}$ of the mixture in a 96 microtiter plate, the absorbance was measured at $510 \mathrm{~nm}$ with the help of a BioTek Synergy HT (Winooski, VT, USA) microplate reader. Quercetin was used as standard for the quantification of flavonoids. The values of TFC were expressed in milligrams of quercetin equivalents per gram of dry extract (mg QE/g extract).

\section{Gas Chromatography-Mass Spectrometry (GC-MS) Analysis}

The $n$-hexane fraction of Dracaena reflexa was analyzed using a GC-MS Agilent 7890B (Santa Clara, CA, USA) with Mass hunter acquisition software. The instrument has an HP-5MS ultra inert capillary non-polar column with proportions of $30 \mathrm{~mm} \times 0.25 \mathrm{~mm}$ ID $\times 0.25 \mu \mathrm{m}$ film. The carrier gas was helium, which was used at a flow of $1.0 \mathrm{~mL} / \mathrm{min}$. At $250{ }^{\circ} \mathrm{C}$, the injector was operated, and the oven temperature was set at $50{ }^{\circ} \mathrm{C}$ for $5 \mathrm{~min}$, then gradually increased to $250{ }^{\circ} \mathrm{C}$ at $100{ }^{\circ} \mathrm{C} / \mathrm{min}$, and lastly to $3000{ }^{\circ} \mathrm{C}$ for $10 \mathrm{~min}$ at $70{ }^{\circ} \mathrm{C} / \mathrm{min}$. The metabolites were identified by assessment with the data of the NIST library while the percentage peak area for each metabolite was computed from the total area of peaks [78].

\subsection{Biological Activity Evaluation}

The antioxidant potentials, enzyme inhibitory effects, and thrombolytic and antibacterial properties were evaluated for the biological activities of the studied Dracaena reflexa. 


\subsubsection{Antioxidant Assays}

Antioxidant assays included determination of the radical scavenging activity and reducing power assays of Dracaena reflexa. Trolox was used as thee standard for all antioxidant assays.

\section{Radical Scavenging Activity}

Two types of analysis were performed for the determination of thee scavenging potential of extract/fractions: 1,1-diphenyl-2-picrylhydrazyl (DPPH) and 2,2-azinobis 3ethylbenzothiazoline-6-sulfonic acid (ABTS) assays. The procedures for DPPH and ABTS assays were accordingly given in the literature with minor modifications [77].

\section{DPPH Assay}

For the DPPH assay radical scavenging assay, $100 \mu \mathrm{L}$ of extract/fractions solution and $400 \mu \mathrm{L}$ of DPPH were mixed in a 96 microtiter plate. This mixture was incubated at ambient temperature for $30 \mathrm{~min}$ in darkness. Absorbance was measured at a wavelength of $517 \mathrm{~nm}$ with the help of a BioTek Synergy HT (Winooski, VT, USA) microplate reader. Results were expressed as Trolox equivalents per gram of extract (mg TE/g extract).

\section{ABTS Assay}

For the ABTS reducing power assay, the formation of ABTS+ radical cation was due to incubation of a mixture of $7 \mathrm{~mm}$ ABTS with $2.45 \mathrm{~mm}$ potassium persulfate in darkness at room temperature. The prepared stock solution of extract/fractions was diluted until its absorbance reached $0.700 \pm 0.02$ at $734 \mathrm{~nm}$. A volume of $100 \mu \mathrm{L}$ of extract/fraction solutions was combined with previously prepared $200 \mu \mathrm{L}$ of ABTS+ solution in a 96 microtiter plate. This mixture was incubated at ambient temperature for $30 \mathrm{~min}$. Absorbance was measured at $734 \mathrm{~nm}$ with the help of a BioTek Synergy HT (Winooski, VT, USA) microplate reader. Results were expressed as millimoles of Trolox equivalents per gram of dry extract. Results of the ABTS assay were expressed as Trolox equivalents per gram of extract (mg TE/g extract).

\section{Reducing Power Assays}

The reducing capacity of Dracaena reflexa extract/fractions was analyzed by utilizing the cupric-reducing antioxidant capacity (CUPRAC) and ferric-reducing antioxidant power (FRAP) assays. These assays were formed according to the methods described in the literature with minor modifications [77]. The results of CUPRAC and FRAP were expressed as milligrams of Trolox equivalents per gram of extract (mg TE/g extract).

\section{CUPRAC Assay}

For the CUPRAC assay, $100 \mu \mathrm{L}$ of extract/fractions solution were added to the reaction mixture $\left[\mathrm{CuCl}_{2}(200 \mu \mathrm{L}, 10 \mathrm{~mm})\right.$, neocuproine $(200 \mu \mathrm{L}, 7.5 \mathrm{~mm}), \mathrm{NH}_{4} \mathrm{Ac}$ buffer $(200 \mu \mathrm{L}$, $1 \mathrm{M}, \mathrm{pH}$ 7.0)], and the absorbance was measured at $450 \mathrm{~nm}$ after $30 \mathrm{~min}$ of incubation at ambient temperature. Furthermore, a blank solution (without the extract/fractions) was prepared and analyzed according to this procedure.

\section{FRAP Assay}

For the FRAP assay, $0.05 \mathrm{~mL}$ of solution were added to $1 \mathrm{~mL}$ of reagent in acetate buffer (0.3 M, pH 3.6), 2,4,6-tris(2-pyridyl)-s-triazine (TPTZ) $(10 \mathrm{~mm})$ in 40-mM HCl and ferric chloride $(20 \mathrm{~mm})$ with a final concentration at the ratio of 10:1:1 $(v / v / v)$. After incubation for $30 \mathrm{~min}$ at ambient temperature, the absorbance was measured at $593 \mathrm{~nm}$. Similarly, a blank sample (prepared in the same manner but without the extract) was prepared. Furthermore, a blank solution (without the extract/fractions) was prepared and analyzed according to this procedure. 


\subsubsection{Enzyme Inhibition Assays}

The potential of extract/fractions of Dracaena reflexa to inhibit the activity of tyrosinase, acetylcholinesterase (AChE), and butyrylcholinesterase (BChE), expressed as \% inhibition, was determined according to procedures described in the literature with minor modifications [77]. The detailed experimental methodology is explained below.

\section{Tyrosinase Inhibition Assay}

A volume of $25 \mu \mathrm{L}$ of solution $(1 \mathrm{mg} / \mathrm{mL})$ of extract/fractions or standard was mixed with $40 \mu \mathrm{L}$ of tyrosinase solution $(200 \mathrm{U} / \mathrm{mL})$ and $100 \mu \mathrm{L}$ of phosphate buffer $(40 \mathrm{~mm}$, $\mathrm{pH}$ 6.8) in a 96 microtiter plate. This solution was incubated for $15 \mathrm{~min}$ at ambient temperature. Then, $40 \mu \mathrm{L}$ of L-DOPA $(10 \mathrm{~mm})$ were added to the incubated mixture for initiation of the reaction. Further, this solution was incubated for $10 \mathrm{~min}$. The absorbance was measured at $492 \mathrm{~nm}$. Kojic acid was used as the standard in the tyrosinase inhibition assay. Similarly, a blank solution (without the extract/fractions or standard) was prepared and analyzed according to this procedure.

Acetylcholinesterase and Butyrylcholinesterase Inhibition Assay

For the $\mathrm{AChE}$ and $\mathrm{BChE}$ inhibition assay, after $15 \mathrm{~min}$ of incubation at $25^{\circ} \mathrm{C}$, the reaction mixture, comprising $50 \mu \mathrm{L}$ of solution of the extract/fraction $(1 \mathrm{mg} / \mathrm{mL}), 125 \mu \mathrm{L}$ of DTNB ( $3 \mathrm{~mm}$ ), and $25 \mu \mathrm{L}$ of enzyme solution $(0.265 \mathrm{U} / \mathrm{mL}$ AChE or $0.026 \mathrm{U} / \mathrm{mL} \mathrm{BChE})$ in Tris- $\mathrm{HCl}$ buffer ( $\mathrm{pH} 8.0$ ), was incubated at ambient temperature for $15 \mathrm{~min}$. Then, $25 \mu \mathrm{L}$ of substrate (15 $\mathrm{mm}$ acetylthiocholine iodide or butyrylthiocholine chloride) were added to the incubated mixture. The absorbance of the final solution was measured at $405 \mathrm{~nm}$ after $15 \mathrm{~min}$. Galanatmine was used as the standard agent for both the acetylcholinesterase and butyrylcholinesterase inhibition assays. Likewise, a blank solution (without the extract/fractions) was prepared and analyzed according to this procedure.

\subsubsection{Thrombolytic Activity of Dracaena reflexa Specimen}

Blood samples for analysis of the in vitro thrombolytic activity were acquired from five healthy volunteers with no history of antidepressants (according to guidelines adopted by the ethical committee). A volume of $5 \mathrm{~mL}$ of sterile water was added to a commercially available lyophilized streptokinase injection $(15,000,000$ i.u.) and mixed and used as the standard for thrombolytic activity.

\section{Study Design}

The Eppendorf tubes were incubated at $37^{\circ} \mathrm{C}$ for $45 \mathrm{~min}$. After clot formation, the serum was completely removed without disturbing the clot, and each Eppendorf tube with a clot was weighed again. To each Eppendorf tube containing a pre-weighted clot, $100 \mu \mathrm{L}(1 \mathrm{mg} / \mathrm{mL})$ of extract/fraction were added. As a positive control or standard, $100 \mu \mathrm{L}$ of streptokinase and negative nonthrombolytic control and $100 \mu \mathrm{L}$ of distilled water were separately added to the Eppendorf tubes. All the loaded Eppendorf tubes were then incubated at $37^{\circ} \mathrm{C}$ for $90 \mathrm{~min}$ and observed for their thrombolytic property. After incubation, the released fluid was removed and the Eppendorf tubes were again weighed. The difference in the weight of the Eppendorf tubes revealed the thrombolytic activity of the extract/fractions and streptokinase [79].

\subsubsection{Antibacterial Activity of $n$-Hexane Fraction \\ Bacterial Strains}

The antibacterial activity of the $n$-hexane fraction of Dracaena reflexa was assessed against eight bacterial strains. Five strains of Gram-positive (Bacillus subtilis, Micrococcus luteus, Staphylococcus epidermidis, Bacillus pumilus, and Staphylococcus aureus) and three strains of Gram-negative (Escherichia coli, Bordetella bronchiseptica, and Pseudomonas aeruginosa) bacteria were used. These bacterial strains were procured from Drug Testing Laboratory 
Bahawalpur, Punjab, Pakistan. Co-amoxiclav was used as the standard antibacterial agent in this assay.

\section{Preparation of Bacterial Inoculum}

Inoculums of each bacteria were prepared by taking a few colonies of each bacteria from the 24-h-old cultures and these colonies were added to test tubes with $10 \mathrm{~mL}$ of sterile nutrient broth medium. These test tubes were then incubated at $37^{\circ} \mathrm{C}$ overnight. The bacterial colonies were diluted to a cell density of $10^{8} \mathrm{CFU} / \mathrm{mL}$.

\section{Disc Diffusion Method}

The antibacterial activity of the $n$-hexane fraction of $D$. reflexa was determined using the disc diffusion method against different bacterial strains. These were strains of some Gram-positive and Gram-negative bacteria that frequently cause infections. The results were depicted in the form of the zone of inhibition measured in millimeters $(\mathrm{mm})$. The solution of $n$-hexane fraction was prepared as $20 \mathrm{mg} / \mathrm{mL}$ by dissolving $50 \mathrm{mg}$ of sample in $2.5 \mathrm{~mL}$ of $10 \mathrm{DMSO}$. A further 2 dilutions of 10 and $5 \mathrm{mg} / \mathrm{mL}$ were prepared from stock solution $(20 \mathrm{mg} / \mathrm{mL})$. These solutions were sterilized by filtering with a sterile $0.45 \mu \mathrm{m}$ membrane filter. Then, $0.1 \mathrm{~mL}$ of bacterial inoculum consisting of $10^{8} \mathrm{CFU} / \mathrm{mL}$ were spread over petri dishes containing $25 \mathrm{~mL}$ of Mueller Hinton agar, and sterile discs (8 mm in diameter) impregnated with $10 \mu \mathrm{L}$ of the fraction solutions $(0.2 \mathrm{mg} / \mathrm{disc}, 0.1 \mathrm{mg} / \mathrm{disc}$, and $0.05 \mathrm{mg} /$ disc) were placed on the surface of the media. Two other types of discs were used, containing 10 DMSO solution and co-amoxiclav (10 $\mu \mathrm{g} / \mathrm{disc})$ as negative and positive controls, respectively. These petri dishes were incubated for $24 \mathrm{~h}$ at $37^{\circ} \mathrm{C}$. These experiments were performed in duplicates. The results were depicted in the form of the zone of inhibition measured in millimeters $(\mathrm{mm})$ and a zone of inhibition greater than $9 \mathrm{~mm}$ was considered as showing antibacterial activity [80].

\subsection{In Silico Molecular Docking Studies}

Molecular docking is a useful tool in the development of molecular biology and computer-aided drug design. A focused search database with an acceptable PDB (Protein Data Bank) format and technique for preparing ligands as PDB files is required for molecular retrieval. To do this, different tools were used, such as autoDock vina software, MGL Tools, Discovery Studio, PyRx, and Babel. The enzyme molecules (tyrosinase, acetylcholinesterase, and butyrylcholinesterase) were downloaded from Protein Data Bank. Further preparation of the enzymes was carried out by Discovery Studio (Discovery Studio 2021 client). Ligand molecules selected from GC-MS and standard compounds were downloaded from the PubChem database in SDF format (structured data format). Ligand molecules were prepared with Babel. These prepared receptors and ligands were uploaded to Vina, which was embedded in PyRx. These structures were placed in the enzyme's catalytic active area with AutoDock vina, and the placement outcomes were evaluated using the Discovery Studio Visualizer [81].

\subsection{Statistical Analysis}

Three biological replicate extract/fractions were analyzed for each assay/activity described above. Results were expressed after deduction of the values for the negative control or blank solution (without extract/fractions) and these results were revealed as the mean \pm standard deviation of the mean (S.D). The data generated from quantitative analysis of the phytochemicals were subjected to IBMSPSS (v20, Chicago, IL, USA) to perform oneway analysis of variance (ANOVA). $p$ values $<0.05$ were considered as significant values.

\section{Conclusions}

The current study explored the methanolic extract, $n$-hexane, chloroform, and $n$ butanol fractions of $D$. reflexa regarding phytochemical analysis and biological activities. The comparative study data showed that the $n$-butanol fraction contained the highest total 
phytochemicals compared to the other extract/fractions, which confirmed its maximum antioxidant and enzyme inhibition (tyrosinase and cholinesterase) activities. The $n$-hexane fraction, due to the presence of antibacterial compounds, was also evaluated against Gram-positive and Gram-negative bacterial strains, which exhibited moderate to good antibacterial activity. The GC-MS analysis of the $n$-hexane fraction provided tentative identification of antibacterial (benzyl benzoate, dodecane, tetradecane, and 5,9-undecadien2-one, 6,10-dimethyl-, (E)-) and other potential secondary metabolites. The tyrosinase, acetylcholinesterase, and butyrylcholinesterase inhibition activities of Dracaena reflexa were further justified by in silico molecular docking studies of GC-MS-identified ligands, betasitosterol, 9,12-octadecadienoic acid, octadecatrienoic acid, methyl ester, vitamin E, alphacadinol, $n$-hexadecanoic acid, and N-hydroxy-N'-[2-(trifluoromethyl)phenyl]pyridine-3carboximidamide, with these enzymes. Further research on fractionation, isolation, and structure elucidation of pure compounds of the extract/fractions of D.reflexa is currently in progress.

Supplementary Materials: The following supporting information can be downloaded online. Figure S1. Antibacterial activity of n-hexane fraction of D.reflexa by disc diffusion method against some bacterial strains; Figure S2. 3D Interaction of tyrosinase and ligands. "A" Beta-Sitosterol, “B" 9,12-Octadecadienoic acid, “C" Octadecatrienoic acid, methyl ester, “D” Vitamin $C$, and “ $E$ " Kojic acid; Figure S3. 3D Interaction of Acetylcholinesterase and ligands. "A" Alpha -Cadinol, "B" n-Hexadecanoic Acid, "C" N-hydroxy-N'-[2-(trifluoromethyl)phenyl]pyridine-3-carboximidamide, and " $\mathrm{D}$ " Galantamine; Figure S4. 3D Interaction of Butyrylcholinesterase and ligands. "A" Alpha-Cadinol, "B" n-Hexadecanoic Acid, "C" N-hydroxy-N'-[2-(trifluoromethyl)phenyl]pyridine-3carboximidamide, and " $\mathrm{D}$ " Galantamine; Table S1. Tyrosinase inhibition (\%) of kojic acid (standard) and extract/fractions of Dracaena reflexa; Table S2. Acetylcholinesterase and butyrylcholinesterase inhibition (\%) of Gantamine (standard) and extract/fractions of Dracaena reflexa; Table S3. Binding affinity and intermolecular forces of Kojic acid, Beta-sitosterol, Octadecadienoic acid, Octadecatrienoic acid methyl ester, and Vitamin E with tyrosinase enzyme; Table S4. Binding affinity and intermolecular forces of Galantamine, Alpha-cadinol, n-hexadecanoic acid, and N-hydroxy- $\mathrm{N}^{\prime}$ [2-(trifluoromethyl)phenyl]pyridine-3-carboximidamide (HTPP) with acetylcholinesterase (AChE); Table S5. Binding affinity and intermolecular forces of Galantamine, Alpha-cadinol, n-hexadecanoic acid, and N-hydroxy-N'-[2-(trifluoromethyl)phenyl]pyridine-3-carboximidamide (HTPP) with butyrylcholinesterase (BChE);

Author Contributions: Conceptualization, B.A.G.; methodology, B.A.G.; software, B.A. and I.A.; validation, H.Y.A. and J.H.A.-Q.; formal analysis, M.N.S.; investigation, M.H.; resources, H.Y.A.; data curation, I.M.; writing—original draft preparation, B.A.G.; writing—review and editing, B.A.G., and K.-u.-R.K.; visualization, S.A.; supervision, K.-u.-R.K. and S.A.; project administration, J.H.A.-Q.; funding acquisition, H.Y.A. and J.H.A.-Q. All authors have read and agreed to the published version of the manuscript.

Funding: The authors are grateful to the King Saud University, Riyadh, Saudi Arabia for funding this study through Project number RSP2022R504.

Institutional Review Board Statement: All the experiments were carried out in accordance with the NIH guidelines and were approved by the Department of Pharmaceutical chemistry's concerned committee (1009/AS \& RB/12/07/2021).

Informed Consent Statement: Not applicable.

Data Availability Statement: Not applicable.

Acknowledgments: The authors are thankful to Researchers Supporting Project number (RSP2022R504), King Saud University, Riyadh, Saudi Arabia. As well as, authors are grateful to Saeed Ahmad, Chairperson Department of Pharmaceutical Chemistry for his technical support, suggestions and laboratory facilities.

Conflicts of Interest: The authors declare no conflict of interest. 


\section{References}

1. Aumeeruddy, M.Z.; Mahomoodally, M.F. Combating breast cancer using combination therapy with 3 phytochemicals: Piperine, sulforaphane, and thymoquinone. Cancer 2019, 125, 1600-1611. [CrossRef] [PubMed]

2. Aumeeruddy-Elalfi, Z.; Lall, N.; Fibrich, B.; Van Staden, A.B.; Hosenally, M.; Mahomoodally, M.F. Selected essential oils inhibit key physiological enzymes and possess intracellular and extracellular antimelanogenic properties in vitro. J. Food Drug Anal. 2018, 26, 232-243. [CrossRef] [PubMed]

3. Veiga, M.; Costa, E.M.; Silva, S.; Pintado, M. Impact of plant extracts upon human health: A review. Crit. Rev. Food Sci. Nutr. 2020, 60, 873-886. [CrossRef] [PubMed]

4. Bursal, E.; Aras, A.; Kılıç, Ö. Evaluation of antioxidant capacity of endemic plant Marrubium astracanicum subsp. macrodon: Identification of its phenolic contents by using HPLC-MS/MS. Nat. Prod. Res. 2019, 33, 1975-1979. [CrossRef] [PubMed]

5. Salehi, B.; Armstrong, L.; Rescigno, A.; Yeskaliyeva, B.; Seitimova, G.; Beyatli, A.; Sharmeen, J.; Mahomoodally, M.F.; Sharopov, F.; Durazzo, A. Lamium plants-A comprehensive review on health benefits and biological activities. Molecules 2019, $24,1913$. [CrossRef]

6. Bursal, E.; Taslimi, P.; Gören, A.C.; Gülçin, İ. Assessments of anticholinergic, antidiabetic, antioxidant activities and phenolic content of Stachys annua. Biocatal. Agric. Biotechnol. 2020, 28, 101711. [CrossRef]

7. Hassan, W.; Noreen, H.; Rehman, S.; Gul, S.; Amjad Kamal, M.; Paul Kamdem, J.; Zaman, B.; BT da Rocha, J. Oxidative stress and antioxidant potential of one hundred medicinal plants. Curr. Top. Med. Chem. 2017, 17, 1336-1370. [CrossRef]

8. Chen, Q.; Wang, Q.; Zhu, J.; Xiao, Q.; Zhang, L. Reactive oxygen species: Key regulators in vascular health and diseases. Br. J. Pharmacol. 2018, 175, 1279-1292. [CrossRef]

9. $\mathrm{Al}$ Rashdi, R.S.Y.; Hossain, M.A.; Al Touby, S.S.J. Antioxidant and antibacterial activities of leaves crude extracts of Adenium obesum grown in Oman National Botanical Garden. Adv. Biomark. Sci. Technol. 2021, 3, 8-14. [CrossRef]

10. Roselan, M.A.; Zakaria, N.; Faujan, N.H.; Latif, M.A.M.; Faudzi, S.M.M.; Ab Hadi, H.; Ashari, S.E. In vitro cytotoxicity assay, mushroom tyrosinase inhibitory activity and release analysis of kojic monooleate nanodelivery system and in silico molecular docking study against 2Y9X target enzyme. J. Drug Deliv. Sci. Technol. 2021, 66, 102764. [CrossRef]

11. Masum, M.N.; Yamauchi, K.; Mitsunaga, T. Tyrosinase inhibitors from natural and synthetic sources as skin-lightening agents. Rev. Agric. Sci. 2019, 7, 41-58. [CrossRef]

12. Zolghadri, S.; Bahrami, A.; Hassan Khan, M.T.; Munoz-Munoz, J.; Garcia-Molina, F.; Garcia-Canovas, F.; Saboury, A.A. A comprehensive review on tyrosinase inhibitors. J. Enzym. Inhib. Med. Chem. 2019, 34, 279-309. [CrossRef] [PubMed]

13. Sabe, V.T.; Ntombela, T.; Jhamba, L.A.; Maguire, G.E.; Govender, T.; Naicker, T.; Kruger, H.G. Current trends in computer aided drug design and a highlight of drugs discovered via computational techniques: A review. Eur. J. Med. Chem. 2021, $224,113705$. [CrossRef]

14. Aras, A.; Türkan, F.; Yildiko, U.; Atalar, M.N.; Kılıç, Ö.; Alma, M.H.; Bursal, E. Biochemical constituent, enzyme inhibitory activity, and molecular docking analysis of an endemic plant species, Thymus migricus. Chem. Pap. 2021, 75, 1133-1146. [CrossRef]

15. Das, R.; Chinnathambi, S. Microglial priming of antigen presentation and adaptive stimulation in Alzheimer's disease. Cell. Mol. Life Sci. 2019, 76, 3681-3694. [CrossRef] [PubMed]

16. Sen, A.; Jette, N.; Husain, M.; Sander, J.W. Epilepsy in older people. Lancet 2020, 395, 735-748. [CrossRef]

17. Sharifi-Rad, M.; Lankatillake, C.; Dias, D.A.; Docea, A.O.; Mahomoodally, M.F.; Lobine, D.; Chazot, P.L.; Kurt, B.; Boyunegmez Tumer, T.; Catarina Moreira, A. Impact of natural compounds on neurodegenerative disorders: From preclinical to pharmacotherapeutics. J. Clin. Med. 2020, 9, 1061. [CrossRef]

18. Thu, Z.M.; Myo, K.K.; Aung, H.T.; Armijos, C.; Vidari, G. Flavonoids and stilbenoids of the genera Dracaena and Sansevieria: Structures and bioactivities. Molecules 2020, 25, 2608. [CrossRef] [PubMed]

19. Luo, Y.; Wang, H.; Xu, X.; Mei, W.; Dai, H. Antioxidant phenolic compounds of Dracaena cambodiana. Molecules 2010, 15, 8904-8914. [CrossRef]

20. Manimaran, P.; Saravanan, S.; Sanjay, M.; Siengchin, S.; Jawaid, M.; Khan, A. Characterization of new cellulosic fiber: Dracaena reflexa as a reinforcement for polymer composite structures. J. Mater. Res. Technol. 2019, 8, 1952-1963. [CrossRef]

21. Narender, B.; Naveena, N.; Pravalika, P.; Kaleem, S.; Vamshi, M.; Mandhadi, J.R. Pharmacological evaluation of root and leaf extracts of Dracaena reflexa var. angustifolia. Innov. Pharm. Pharmacother. 2017, 5, 141-146.

22. Fay, M.; Risher, J.; Wilson, J.D. Toxicological Profile for Xylene; U.S. Department for Health and Human Services: Washington, DC, USA, 2007.

23. Padma, M.; Ganesan, S.; Jayaseelan, T.; Azhagumadhavan, S.; Sasikala, P.; Senthilkumar, S.; Mani, P. Phytochemical screening and GC-MS analysis of bioactive compounds present in ethanolic leaves extract of Silybum marianum (L). J. Drug Deliv. Ther. 2019, 9, 85-89. [CrossRef]

24. Yu, F.-R.; Lian, X.-Z.; Guo, H.-Y.; McGuire, P.M.; Li, R.-D.; Wang, R.; Yu, F.-H. Isolation and characterization of methyl esters and derivatives from Euphorbia kansui (Euphorbiaceae) and their inhibitory effects on the human SGC-7901 cells. J. Pharm. Pharm. Sci. 2005, 8, 528-535. [PubMed]

25. Rahbar, N.; Shafaghat, A.; Salimi, F. Antimicrobial activity and constituents of the hexane extracts from leaf and stem of Origanum vulgare L. ssp. Viride (Boiss.) Hayek. growing wild in Northwest Iran. J. Med. Plants Res. 2012, 6, 2681-2685.

26. Ugbogu, E.A.; Akubugwo, I.E.; Ude, V.C.; Gilbert, J.; Ekeanyanwu, B. Toxicological evaluation of phytochemical characterized aqueous extract of wild dried Lentinus squarrosulus (Mont.) mushroom in rats. Toxicol. Res. 2019, 35, 181-190. [CrossRef] 
27. Uma, B.; Parvathavarthini, R. Antibacterial effect of hexane extract of sea urchin, Temnopleurus alexandri (Bell, 1884). Int. J. Pharm. Technol. Res. 2010, 2, 1677-1680.

28. Ja, D. Dr. Duke's Phytochemical and Ethnobotanical Databases. Chemicals in Vitis vinifera L. (VItaceae); Ag Data Commons: Beltsville, MD, USA, 2012

29. Ren, J.; Wang, J.; Karthikeyan, S.; Liu, H.; Cai, J. Natural anti-phytopathogenic fungi compound phenol, 2, 4-bis (1, 1-dimethylethyl) from Pseudomonas fluorescens TL-1. Indian J. Biochem. Biophys. (IJBB) 2019, 56, 162-168.

30. Mou, Y.; Meng, J.; Fu, X.; Wang, X.; Tian, J.; Wang, M.; Peng, Y.; Zhou, L. Antimicrobial and antioxidant activities and effect of 1-hexadecene addition on palmarumycin C2 and C3 yields in liquid culture of endophytic fungus Berkleasmium sp. Dzf12. Molecules 2013, 18, 15587-15599. [CrossRef]

31. Bruno, F.; Castelli, G.; Migliazzo, A.; Piazza, M.; Galante, A.; Verde, V.L.; Calderone, S.; Nucatolo, G.; Vitale, F. Cytotoxic screening and in vitro evaluation of pentadecane against Leishmania infantum promastigotes and amastigotes. J. Parasitol. 2015, 101, 701-705. [CrossRef]

32. Di Stefano, V.; Pitonzo, R.; Schillaci, D. Antimicrobial and antiproliferative activity of Athamanta sicula L. (Apiaceae). Pharmacogn. Mag. 2011, 7, 31. [CrossRef]

33. Singh, S.; Sankar, B.; Rajesh, S.; Sahoo, K.; Subudhi, E.; Nayak, S. Chemical composition of turmeric oil (Curcuma longa L. cv. Roma) and its antimicrobial activity against eye infecting pathogens. J. Essent. Oil Res. 2011, 23, 11-18. [CrossRef]

34. Stanojević, J.S.; Stanojević, L.P.; Cvetković, D.J.; Danilović, B.R. Chemical composition, antioxidant and antimicrobial activity of the turmeric essential oil (Curcuma longa L.). Adv. Technol. 2015, 4, 19-25. [CrossRef]

35. Belakhdar, G.; Benjouad, A.; Abdennebi, E. Determination of some bioactive chemical constituents from Thesium humile Vahl. J. Mater. Environ. Sci. 2015, 6, 2778-2783.

36. Rouis-Soussi, L.S.; El Ayeb-Zakhama, A.; Mahjoub, A.; Flamini, G.; Jannet, H.B.; Harzallah-Skhiri, F. Chemical composition and antibacterial activity of essential oils from the Tunisian Allium nigrum L. EXCLI J. 2014, 13, 526.

37. Beulah, G.; Soris, P.T.; Mohan, V. GC-MS Determination of Bioactive Compounds of Dendrophthoe falcata (LF) Ettingsh: An Epiphytic Plant. Int. J. Health Sci. Res. 2018, 8, 261-269.

38. Handique, J.G.; Gogoi, D.; Bora, G.; Borgohain, R. Antioxidant Capacity and GC-MS Analysis of Hexane, Ethylacetate and Methanol Extracts of Ficus bhotanica-A Potential Folklore Medicinal Plant. Int. J. Pharmacogn. Phytochem. Res. 2018, 10, $201-212$.

39. Banakar, P.; Jayaraj, M. GC-MS analysis of bioactive compounds from ethanolic leaf extract of Waltheria indica Linn. and their pharmacological activities. Int. J. Pharm. Sci. Res. 2018, 9, 2005-2010.

40. Zayed, M.Z.; Ahmad, F.B.; Ho, W.-S.; Pang, S.-L. GC-MS analysis of phytochemical constituents in leaf extracts of Neolamarckia cadamba (Rubiaceae) from Malaysia. Int. J. Pharm. Pharm. Sci 2014, 6, 123-127.

41. Krishnamoorthy, K.; Subramaniam, P. Phytochemical profiling of leaf, stem, and tuber parts of Solena amplexicaulis (Lam.) Gandhi using GC-MS. Int. Sch. Res. Not. 2014, 2014, 567409. [CrossRef]

42. Rahman, M.; Ahmad, S.; Mohamed, M.; Ab Rahman, M. Antimicrobial compounds from leaf extracts of Jatropha curcas, Psidium guajava, and Andrographis paniculata. Sci. World J. 2014, 2014, 635240. [CrossRef]

43. Elsayed, T.R.; Galil, D.F.; Sedik, M.Z.; Hassan, H.M.; Sadik, M.W. Antimicrobial and Anticancer Activities of Actinomycetes Isolated from Egyptian Soils. Int. J. Curr. Microbiol. Appl. Sci. 2020, 9, 2020. [CrossRef]

44. Lal, R.; Jat, B.L. Bio-efficacy of insecticides and biorationals against the incidence of whitefly, Bemisia tabaci (Genn.) and yellow mosaic virus in mungbean. Afr. J. Agric. Res. 2015, 10, 1050-1056.

45. Jemal, K. Molecular Docking Studies of Phytochemicals of Allophylus serratus against Cyclooxygenase-2 Enzyme. bioRxiv 2019, 866152. [CrossRef]

46. Nimbeshaho, F.; Mwangi, C.N.; Orina, F.; Chacha, M.; Adipo, N.; Moody, J.O.; Kigondu, E.M. Antimycobacterial activities, cytotoxicity and phytochemical screening of extracts for three medicinal plants growing in Kenya. J. Med. Plants Res. 2020, 14, 129-143.

47. Joseph, D.D.; Veerasamy, K.; Singaram, S.S. Identification of bioactive compounds by gas chromatography-mass spectrometry analysis of Syzygium jambos (L.) collected from Western Ghats region Coimbatore, Tamil Nadu. Asian J. Pharm. Clin. Res. 2016, 10, 364-369. [CrossRef]

48. Bae, M.-S.; Park, J.K.; Kim, K.-H.; Cho, S.-S.; Lee, K.-Y.; Shon, Z.-H. Emission and cytotoxicity of surgical smoke: Cholesta-3, 5-diene released from pyrolysis of prostate tissue. Atmosphere 2018, 9, 381. [CrossRef]

49. Lakshmi, M.; Nair, B.R. GC-MS analysis of the chloroform extract of bark of Terminalia travancorensis Wight \& Arn. (Combretaceae). Int. J. Pharm. Sci. Res. 2017, 8, 794.

50. Kaur, N.; Chaudhary, J.; Jain, A.; Kishore, L. Stigmasterol: A comprehensive review. Int. J. Pharm. Sci. Res. 2011, 2, 2259.

51. Lee, V.H. Changing needs in drug delivery in the era of peptide and protein drugs. Pept. Protein Drug Deliv. 1991, 1, 1-56.

52. Mitchell, W.L.; Giblin, G.M.; Naylor, A.; Eatherton, A.J.; Slingsby, B.P.; Rawlings, A.D.; Jandu, K.S.; Haslam, C.P.; Brown, A.J.; Goldsmith, P. Pyridine-3-carboxamides as novel CB2 agonists for analgesia. Bioorg. Med. Chem. Lett. 2009, 19, 259-263. [CrossRef]

53. Hasan, A.; Artika, I.; Kuswandi, T.G. Analysis of active components of Trigona spp propolis from Pandeglang Indonesia. Glob. J. Biol. Agric. Health Sci. 2014, 3, 215-219.

54. Ladokun, O.A.; Abiola, A.; Okikiola, D.; Ayodeji, F. GC-MS and molecular docking studies of Hunteria umbellata methanolic extract as a potent anti-diabetic. Inform. Med. Unlocked 2018, 13, 1-8. [CrossRef] 
55. Atanassova, M.; Georgieva, S.; Ivancheva, K. Total phenolic and total flavonoid contents, antioxidant capacity and biological contaminants in medicinal herbs. J. Univ. Chem. Technol. Metall. 2011, 46, 81-88.

56. Urzúa, A.; Rezende, M.C.; Mascayano, C.; Vásquez, L. A structure-activity study of antibacterial diterpenoids. Molecules 2008, 13, 882-891. [CrossRef]

57. Shukla, A.; Vats, S.; Shukla, R. Phytochemical screening, proximate analysis and antioxidant activity of Dracaena reflexa Lam. leaves. Indian J. Pharm. Sci. 2015, 77, 640. [CrossRef]

58. Magder, S. Reactive oxygen species: Toxic molecules or spark of life? Crit. Care 2006, 10, 208. [CrossRef]

59. Marín, L.; Miguélez, E.M.; Villar, C.J.; Lombó, F. Bioavailability of dietary polyphenols and gut microbiota metabolism: Antimicrobial properties. BioMed Res. Int. 2015, 2015, 905215. [CrossRef]

60. Karak, P. Biological activities of flavonoids: An Overview. Int. J. Pharm. Sci. Res. 2019, 10, 1567-1574.

61. Aras, A.; Bursal, E.; Türkan, F.; Tohma, H.; Kılıç, Ö.; Gülçin, İ.; Köksal, E. Phytochemical content, antidiabetic, anticholinergic, and antioxidant activities of endemic Lecokia cretica extracts. Chem. Biodivers. 2019, 16, e1900341. [CrossRef]

62. Sethi, S.; Joshi, A.; Arora, B.; Bhowmik, A.; Sharma, R.; Kumar, P. Significance of FRAP, DPPH, and CUPRAC assays for antioxidant activity determination in apple fruit extracts. Eur. Food Res. Technol. 2020, 246, 591-598. [CrossRef]

63. Zuo, A.-R.; Dong, H.-H.; Yu, Y.-Y.; Shu, Q.-L.; Zheng, L.-X.; Yu, X.-Y.; Cao, S.-W. The antityrosinase and antioxidant activities of flavonoids dominated by the number and location of phenolic hydroxyl groups. Chin. Med. 2018, 13, 51. [CrossRef] [PubMed]

64. Uchida, R.; Ishikawa, S.; Tomoda, H. Inhibition of tyrosinase activity and melanine pigmentation by 2-hydroxytyrosol. Acta Pharm. Sin. B 2014, 4, 141-145. [CrossRef] [PubMed]

65. Chang, T.S. Review an update review of tyrosinase inhibitors Intern. Int. J. Mol. Sci. 2009, 10, 2440-2475. [CrossRef] [PubMed]

66. Wszelaki, N.; Kuciun, A.; Kiss, A. Screening of traditional European herbal medicines for acetylcholinesterase and butyrylcholinesterase inhibitory activity. Acta Pharm. 2010, 60, 119. [CrossRef] [PubMed]

67. Alecu, A.; Albu, C.; Litescu, S.C.; Eremia, S.A.; Radu, G.L. Phenolic and anthocyanin profile of Valea Calugareasca red wines by HPLC-PDA-MS and MALDI-TOF analysis. Food Anal. Methods 2016, 9, 300-310. [CrossRef]

68. Magalhães, V.; Rios, R.M.; Silva, F.G.; Dias, A.C. Comparative Study on the Inhibition of Acetylcholinesterase Activity by Hyptis marrubioides, Hyptis pectinata, and Hyptis suaveolens Methanolic Extracts. Proceedings 2020, 70, 81. [CrossRef]

69. Mukherjee, P.K.; Kumar, V.; Mal, M.; Houghton, P.J. Acetylcholinesterase inhibitors from plants. Phytomedicine 2007, 14, 289-300. [CrossRef]

70. Khan, H.; Amin, S.; Kamal, M.A.; Patel, S. Flavonoids as acetylcholinesterase inhibitors: Current therapeutic standing and future prospects. Biomed. Pharmacother. 2018, 101, 860-870. [CrossRef]

71. Middleton, J.M.D.E. Biological properties of plant flavonoids: An overview. Int. J. Pharmacogn. 1996, 34, 344-348. [CrossRef]

72. Xin, N.; Li, Y.-J.; Li, Y.; Dai, R.-J.; Meng, W.-W.; Chen, Y.; Schlappi, M.; Deng, Y.-L. Dragon's Blood extract has antithrombotic properties, affecting platelet aggregation functions and anticoagulation activities. J. Ethnopharmacol. 2011, 135, 510-514. [CrossRef]

73. Chowdhury, S.; Sharmin, T.; Hoque, M.; Sumsujjaman, M.; Das, M.; Nahar, F. Evaluation of Thrombolytic and membrane stabilizing activities of four medicinal plants of Bangladesh. Int. J. Pharm. Sci. Res. 2013, 4, 4223.

74. Kazłowska, K.; Hsu, T.; Hou, C.-C.; Yang, W.-C.; Tsai, G.-J. Anti-inflammatory properties of phenolic compounds and crude extract from Porphyra dentata. J. Ethnopharmacol. 2010, 128, 123-130. [CrossRef] [PubMed]

75. Aljubiri, S.M.; Mahgoub, S.A.; Almansour, A.I.; Shaaban, M.; Shaker, K.H. Isolation of diverse bioactive compounds from Euphorbia balsamifera: Cytotoxicity and antibacterial activity studies. Saudi J. Biol. Sci. 2021, 28, 417-426. [CrossRef] [PubMed]

76. Truong, D.-H.; Nguyen, D.H.; Ta, N.T.A.; Bui, A.V.; Do, T.H.; Nguyen, H.C. Evaluation of the use of different solvents for phytochemical constituents, antioxidants, and in vitro anti-inflammatory activities of Severinia buxifolia. J. Food Qual. 2019, 2019, 8178294. [CrossRef]

77. Grochowski, D.M.; Uysal, S.; Zengin, G.; Tomczyk, M. In vitro antioxidant and enzyme inhibitory properties of Rubus caesius L. Int. J. Environ. Health Res. 2019, 29, 237-245. [CrossRef] [PubMed]

78. Hayat, M.M.; Uzair, M. Biological potential and GC-MS analysis of phytochemicals of Farsetia hamiltonii (Royle). Biomed. Res. 2019, 30. [CrossRef]

79. Tabassum, F.; Chandi, S.H.; Mou, K.N.; Hasif, K.; Ahamed, T.; Akter, M. Invitro thrombolytic activity and phytochemical evaluation of leaf extracts of four medicinal plants of Asteraceae family. J. Pharmacogn. Phytochem. 2017, 6, 1166-1169.

80. Rahmoun, N.M.; Ziane, H.; Boucherit-Otmani, Z. Antibacterial and antifungal screening of four medicinal plants. J. Coast. Life Med. 2014, 2, 975-979.

81. Meng, X.-Y.; Zhang, H.-X.; Mezei, M.; Cui, M. Molecular docking: A powerful approach for structure-based drug discovery. Curr. Comput.-Aided Drug Des. 2011, 7, 146-157. [CrossRef] 